\title{
Review
}

\section{Coatings Functionalization via Laser versus Other Deposition Techniques for Medical Applications: A Comparative Review}

\author{
Maria Badiceanu ${ }^{1,2, *}$, Sinziana Anghel ${ }^{1,2, *}$, Natalia Mihailescu ${ }^{1, *}$, Anita Ioana Visan ${ }^{1, *(\mathbb{D} \text {, }}$ \\ Cristian N. Mihailescu ${ }^{1, *}$ and Ion N. Mihailescu $1, * \mathbb{C}$ \\ 1 National Institute for Laser, Plasma and Radiation Physics, Magurele, Ilfov, RO-077125 Muntenia, Romania \\ 2 Faculty of Physics, University of Bucharest, Magurele, Ilfov, RO-077125 Muntenia, Romania \\ * Correspondence: badiceanu.maria@inflpr.ro (M.B.); sanziana.anghel@inflpr.ro (S.A.); \\ natalia.mihailescu@inflpr.ro (N.M.); anita.visan@inflpr.ro (A.I.V.); cristi.mihailescu@inflpr.ro (C.N.M.); \\ ion.mihailescu@inflpr.ro (I.N.M.)
}

check for updates

Citation: Badiceanu, M.; Anghel, S.; Mihailescu, N.; Visan, A.I.

Mihailescu, C.N.; Mihailescu, I.N. Coatings Functionalization via Laser versus Other Deposition Techniques for Medical Applications: A Comparative Review. Coatings 2022, 12, 71. https://doi.org/10.3390/ coatings12010071

Academic Editor:

Natalia V. Kamanina

Received: 17 November 2021

Accepted: 22 December 2021

Published: 7 January 2022

Publisher's Note: MDPI stays neutral with regard to jurisdictional claims in published maps and institutional affiliations.

Copyright: (c) 2022 by the authors Licensee MDPI, Basel, Switzerland. This article is an open access article distributed under the terms and conditions of the Creative Commons Attribution (CC BY) license (https:// creativecommons.org/licenses/by/ $4.0 /)$.
Abstract: The development of new biological devices in response to market demands requires continuous efforts for the improvement of products' functionalization based upon expansion of the materials used and their fabrication techniques. One viable solution consists of a functionalization substrate covered by layers via an appropriate deposition technique. Laser techniques ensure an enhanced coating's adherence to the substrate and improved biological characteristics, not compromising the mechanical properties of the functionalized medical device. This is a review of the main laser techniques involved. We mainly refer to pulse laser deposition, matrix-assisted, and laser simple and double writing versus some other well-known deposition methods as magnetron sputtering, 3D bioprinting, inkjet printing, extrusion, solenoid, fuse-deposition modeling, plasma spray (PS), and dip coating. All these techniques can be extended to functionalize surface fabrication to change local morphology, chemistry, and crystal structure, which affect the biomaterial behavior following the chosen application. Surface functionalization laser techniques are strictly controlled within a confined area to deliver a large amount of energy concisely. The laser deposit performances are presented compared to reported data obtained by other techniques.

Keywords: surface functionalization; medical applications; direct laser writing; MAPLE/C-MAPLE; magnetron sputtering; $3 \mathrm{D}$ bioprinting

\section{Introduction}

Functionalization of coatings for medical purposes by tailoring the initial features of the used biomaterial can lead to entirely new and challenging application perspectives, improving the biological properties of the final medical device [1]. In this review, we will discuss how physical functionalization can be used to produce multiple changes to the biomaterials' surface morphology and chemistry in order to enhance the proteins' and cells' adhesion for applications such as biomedical implants.

Surface functionalization by coating/covering implies a manufacturing process in which a precursor material is delivered to a surface on which it reorganizes by an interplay between thermodynamics and kinetics [2,3].

Generally, the basic steps in the growth of materials by deposition are the emission of the species intended to be deposited from a source (i.e., pulsed laser-an irradiated target for inducing ablation, high voltage for generating charged particle beams, heater for thermionic emission), their transport from the source (target) to the system supporting the growing deposit (substrate) nucleation, and subsequent growth by condensation processes of the deposited species [4,5]. The depositing species can diffuse under the drive of both their self-energy and their substrate thermal energy and then move to a stable position on the substrate, where surrounding atoms may be captured and incorporated, leading to the 
primary stage of growth, that is, nucleation [6]. Condensation develops through stages: formation of clusters (i.e., groups of deposited species linked by a neighborhood relation), nucleation (formation of stable clusters), dynamics of unstable and stable clusters, formation of an "island" (growing nuclei) and its growth, island coalescence, percolation, and structure development (amorphous, polycrystalline, single crystalline, defects, roughness, and grain growth) [7-9].

Thus, depending on the deposition approach and the underlying mechanisms which appear in the morphological and structural evolution, the functional source materials' properties and performances can be tailored at an atomic scale (Figure 1).

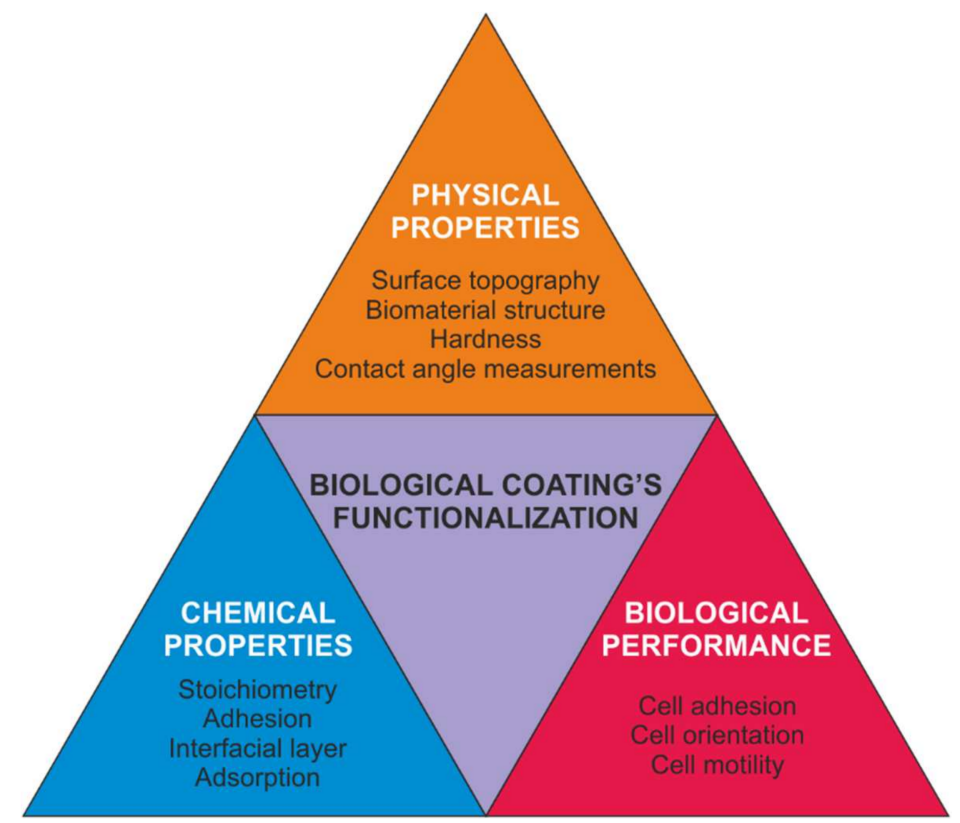

Figure 1. Surface coating functionalization-correlation and influence on the physical, chemical, and biological properties.

Various studies have shown the potentiality of different coating functionalization techniques to control the surface properties of biomaterials and enhance their biological performance.

Different strategies (mechanical, physical, chemical, and biological) are utilized to functionalize material surfaces. These techniques (Table 1) can be used individually or in combination.

Each method has specific advantages and limitations. One should select the best compromise in terms of implant materials, concrete situations, and fabrication procedures [9]. In particular, mechanical functionalization uses appropriate machining, polishing, and/or irradiation procedures to get a surface with a specific roughness optimal for cell proliferation and cell adhesion [10-12]. Physical functionalization methods (i.e., chemical vapor deposition and cold vapor deposition (CVD), pulsed laser deposition (PLD), sol-gel deposits, micro-arc oxidations, hydrothermal treatments, or electrochemical deposition) include processes like oxidation (for metal and alloy passivation), but also surface coating leading to protection or activation [12,13].

Chemical and biological functionalization are related to two principal concepts (i.e., drug delivery systems (DDS) and the grafting of bioactive compounds on small strongly (covalently) bound spacer molecules). In the first DDS concept, the bioactive molecules go to the target, the biodegradable substrate is dissolved with subsequent release of bioactive molecules. Molecules grafted on cage ones or biomimetic and implant coatings are released, under control of bioactive molecules [12]. In the other concept, the target goes to the bioactive molecules. Concretely, nearly any substrate can be functionalized, with a huge choice of active molecules, for example, anti-coagulant, antiproliferative, anti-inflammatory, 
anti-mitotic agents, antibiotics, extracellular matrix proteins, and growth factors. These procedures immobilize the bioactive molecule on the biomaterial surface [12].

Table 1. Summary of surface functionalization techniques.

\begin{tabular}{|c|c|c|c|}
\hline $\begin{array}{l}\text { Strategies for Material Surfaces } \\
\text { Functionalization }\end{array}$ & Techniques & Remarks & Refs. \\
\hline Mechanical functionalization & Polishing processes & $\begin{array}{l}\text { The expression of protein adhesion varies } \\
\text { concerning the surface roughness. These } \\
\text { results indicate a direct relationship } \\
\text { between the decrease of cell adhesion and } \\
\text { the increase of cell proliferation on } \\
\text { mirror-polished materials. }\end{array}$ & [10] \\
\hline \multirow{8}{*}{$\begin{array}{l}\text { Physical } \\
\text { functionalization methods }\end{array}$} & Plasma spraying (PS) & Thermal technique; economical and safe. & {$[14]$} \\
\hline & Physical vapor deposition (PVD) & $\begin{array}{l}\text { Vacuum deposition; utilize all inorganic } \\
\text { and some organic materials; strong } \\
\text { adhesion. }\end{array}$ & {$[15]$} \\
\hline & Machining & $\begin{array}{l}\text { A simple method to increase roughness; } \\
\text { slow and inefficient. }\end{array}$ & {$[16]$} \\
\hline & Laser treatment & $\begin{array}{l}\text { Achieving complex and precise } \\
\text { topography; rapid and clean. }\end{array}$ & [17] \\
\hline & 3D bioprinting & $\begin{array}{l}\text { Producing complex 3D structures; } \\
\text { uncomplicated process; energy and } \\
\text { biomaterials saving. }\end{array}$ & [18] \\
\hline & $\begin{array}{l}\text { Combinatorial-matrix-assisted pulsed } \\
\text { laser evaporation technique (C-MAPLE) }\end{array}$ & $\begin{array}{l}\text { Allows the manufacture of thin films from } \\
\text { two combined organic materials and the } \\
\text { identification of the optimal dosage in the } \\
\text { deposited structures. }\end{array}$ & {$[19,20]$} \\
\hline & Magnetron sputtering & $\begin{array}{l}\text { Strong adherence to the substrate, wide } \\
\text { range of coating materials. }\end{array}$ & {$[21,22]$} \\
\hline & Direct laser transfer (LDW) & $\begin{array}{c}\text { A simple, versatile, and very } \\
\text { advantageous method of obtaining } \\
\text { structures from various materials arranged } \\
\text { in a controlled geometric pattern. }\end{array}$ & [23] \\
\hline \multirow{6}{*}{ Chemical functionalization } & Sol-gel & $\begin{array}{l}\text { Low-temperature technique; drugs } \\
\text { delivery. }\end{array}$ & [24] \\
\hline & Anodic oxidation (anodization) & $\begin{array}{l}\text { An accelerated electrochemical process; } \\
\text { enhancing the corrosion resistance, } \\
\text { creating nanometer features. }\end{array}$ & [25] \\
\hline & Chemical vapor deposition (CVD) & $\begin{array}{l}\text { Generating a fine and solid film; creating } \\
\text { both homogeneous and hierarchical } \\
\text { structures. }\end{array}$ & [26] \\
\hline & Alkali treatment & $\begin{array}{l}\text { Extending uniformly; do not damage } \\
\text { mechanical properties. }\end{array}$ & [27] \\
\hline & Acid etching & $\begin{array}{l}\text { Removing materials and fabricating } \\
\text { roughness, depending on acid } \\
\text { concentration, temperature, and time. }\end{array}$ & {$[28]$} \\
\hline & Proteins & VEGF, ECM. & [29] \\
\hline Biological functionalization & Cells & $\begin{array}{c}\text { AMSCs, BMSCs, MSCs, embryonic stem } \\
\text { cells. }\end{array}$ & [30] \\
\hline
\end{tabular}

However, more research is needed to obtain the desired biological response and move the research into the industrial zone. In addition, one of the main problems of different coating functionalization methods is to guarantee proper adhesion to the surface $[31,32]$. Furthermore, the mixture of different bioactive materials can drastically reduce the mechanical properties of coatings. One viable solution to all these drawbacks consists of applying a physical surface functionalization that can enhance the biological properties without compromising their mechanical properties [33]. Physical vapor deposition (PVD) technology implies a physical process (such as evaporation (e.g., LDW, MAPLE, C-MAPLE) or sputtering (e.g., magnetron sputtering)) to produce a vapor of target material, which is then deposited on the medical device which requires coating. The coating provided 
by PVD technology exhibits strong bonding force with the substrate, super-hard surface hardness, excellent corrosion resistance, and good biocompatibility [34].

Among the physical functionalization methods, the advanced laser ones (i.e., direct laser transfer (LDW), matrix-assisted pulsed laser evaporation technique (MAPLE), and combinatorial-MAPLE (C-MAPLE)) present attractive advantages, such as good adhesion of deposited material to substrate, coating uniformity, controlled thickness, experiment reproducibility, and stoichiometry. One of the significant advantages of the laser as a tool for surface functionalization is precisely controlling where in the biomaterial and at what rate energy is deposited [21,35]. By choosing the appropriate laser parameters, precise control of the final functionalized surface is exercised by properly selecting laser processing parameters to achieve the desired material modification. It enables processing procedures to be designed and optimized to provide the best biomaterial functionality and a reproducible method protocol to be achieved [36,37]. Laser and sputtering techniques are ecological (because they are conducted under very low ambient pressure and materials are not contaminated). Other laser methods imply only a low consumption of material, which is the case of the MAPLE deposition technique. In addition, some materials can only be deposited with a laser [38,39].

On the other hand, the PVD magnetron sputtering processes could be carried out in a vacuum to depose any alloys or metals on any substrate with high efficiency while guaranteeing the functionality and uniformity of the final desired medical device [39].

PVD Coatings can also solve common 3D-printed mold and part problems; the right physical surface functionalization solution can alleviate a few common additives' manufacturing drawbacks that typically require creating new molds or parts. The production speed of PVD coatings is slow compared to other coating deposition processes, for example, 3D bioprinting, which became a booming technology, particularly in the medical field (e.g., implantable parts for the orthopedic, instrument, spinal, and custom markets). It makes it possible to achieve different medical device surface finishes, details, and production speeds to meet the target properties and price.

This review is devoted to selected modifications of biomaterial surfaces currently used in medical clinical practice.

To improve manuscript organization and readability, the manuscript flow chart is presented in Figure 2.

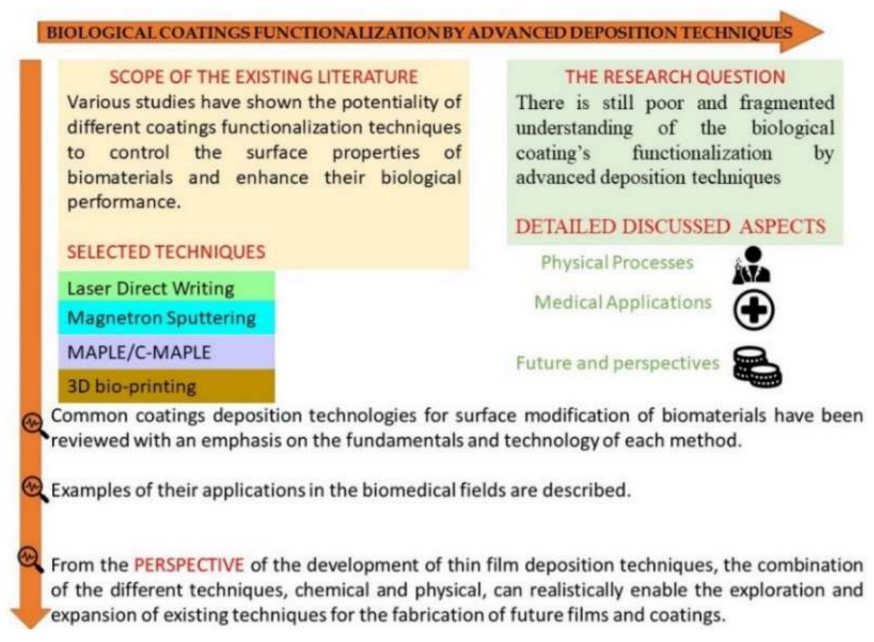

Figure 2. Manuscript flowchart.

Reported results show an understanding of biological coating functionalization by advanced deposition techniques that is still poor and fragmented. There exist many studies in dedicated literature on the functionalization of coatings by many methods for a large range of applications. However, only a few of them addressed the medical ones. These 
statistics fully support the need for the present centralization of information, and a detailed discussion of the results is considered in this review.

\section{Surface Functionalization Techniques for Medical Applications}

A complete approach of all surface modification techniques and applications is beyond the scope of a single review paper, so we will primarily focus on four specific case studies in which new biological applications are actively being developed.

The main applications discussed here involve laser techniques (e.g., pulse laser deposition, matrix-assisted, laser simple and double writing). Some other notorious deposition methods (such as magnetron sputtering, 3D bioprinting, inkjet printing, extrusion, solenoid, fuse-deposition modeling, plasma spray (PS), and dip coating) will be also presented comparatively.

For example, an exciting approach was reported by Abegunde [4], consisting of two subsequent laser depositions.

The method was used to improve thermally sprayed metals' properties, alloys, composites, ceramics, thermal barriers, wear resistance, and corrosion-resistant and/or wearresistant engraved coatings (anilox rolls).

A comparative study between hydroxyapatite coatings synthesized by plasma spray (PS) versus pulsed-laser deposition (PLD) was reported [40]. Plasma spray is commercially used for coating dental and orthopaedical implant devices. At the same time, pulsed-laser deposition (or laser-ablation deposition) gave good results in the field of high critical temperature superconductive thin films and is currently applied to produce calcium phosphate coatings for biomedical purposes.

The study reveals that the PLD technique is a good candidate for replacing the plasma spray in many biomedical applications because it overcomes most of the shortcomings of this technique.

Coatings based upon lysozyme embedded into a matrix of polyethylene glycol (PEG) and polycaprolactone (PCL) were fabricated by MAPLE and dip coating for obtaining antimicrobial coatings for long-term medical applications.

The primary surface features were measured, along with impact on roughness and wettability, microbial adhesion, and eukaryote cell function. Synthesized composite coatings demonstrated a notable antibacterial activity against Escherichia coli, Bacillus subtilis, Enterococcus faecalis, and Staphylococcus aureus strains. Moreover, selected blended layers showed adequate viability, good spreading, and normal cell morphology of SaOs2 human osteoblasts and mesenchymal stem cells (MSCs). According to the reported results, biodegradable composites proved suitable for implant coatings that decreased the risk of bacterial contamination associated with prosthetic procedures [41].

Coated microneedles can be used to increase drug loading further, and to dip or spray aqueous solution with high viscosity using layer-by-layer coating techniques. Negatively charged DNA or viruses are absorbed onto positively charged microneedles via electrostatic attraction to easily attain microneedle coating [42].

Thus, in this section, an overview of the coating's functionalization for medical purposes will be presented to provide the basic information and knowledge to a reader new to the subject of coating functionalization. Four individual coating methods will be detailed, namely direct laser transfer (LDW), matrix-assisted pulsed laser evaporation (MAPLE), combinatorial-matrix-assisted pulsed laser evaporation (C-MAPLE), and magnetron sputtering or 3D bioprinting methods. Before delving into these case studies, we start with a short overview (in Figure 3) of the surface functionalization coating methods (focusing on the techniques detailed in the following subsections), which can be used for the controlled microstructure of biomaterials. 


\section{CLASSIFICATION OF PROCESSES USED FOR MEDICAL COATINGS FUNCTIONALIZATION}
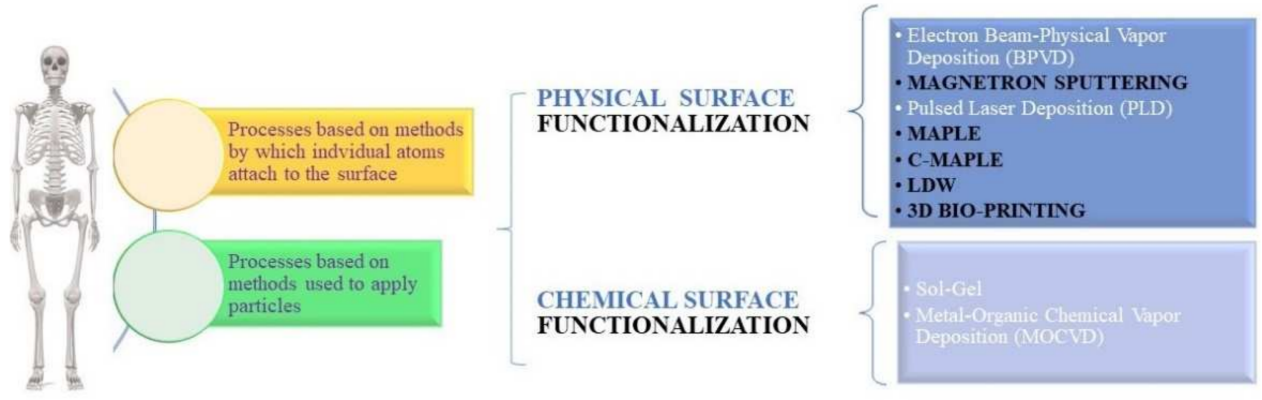

Figure 3. Deposition methods used for surface functionalization at the industrial level.

Some physical insights into the mechanisms and processes involved in deposition techniques will be discussed. The underlying connections between experimental conditions and the resulting structure and morphology will also be discussed to establish a foundation for further specific readings.

As mentioned earlier, the possibility of validating biomaterials' new properties is strictly connected to the availability of manufacturing processes and characterization techniques. Among fabrication methods, the selected advanced deposition techniques offer several advantages compared to "traditional" ones for the fabrication of surface functionalization due to the possibility of tuning many independent processing parameters.

\subsection{Direct Laser Transfer (LDW)}

One of the most versatile direct-write techniques, LDW allows modification, addition, and removal of the material from a target without any physical contact. Furthermore, this technique facilitates complex material processing, having resolutions from microns to millimeters. This way, LDW is ideal for fabricating structures; otherwise, it would be impossible to achieve with other techniques.

The LDW set-up must contain a laser source, an essential part, the beam delivery pathway, and the substrate material translation system. Many lasers, from continuous wave $(\mathrm{CW})$ to ultrafast pulsed lasers, have been used in LDW processing. The main factor in determining the appropriate laser source and its parameters (wavelength, pulse duration, beam quality, divergence) is the fundamental interaction between laser and target material. These parameters directly determine the efficiency of the energy absorption and the response of subsequent material [35].

In recent years, direct laser transfer techniques have received significant attention because they are simple, versatile, and advantageous methods used for obtaining different kinds of structures arranged in a controlled geometric manner.

In this technique, the laser beam is focused on the surface of an already deposited thin film (the target) through transparent support. The transferred material is deposited onto the substrate placed parallel in the sample vicinity at a certain distance. After passing through the support, a single laser pulse ablates a narrow region at the interface of the "donor" layer. The irradiated material is propelled perpendicular to the target due to the pressure accumulation inside the layer mentioned above [43]. In Figures 4 and 5, one can find the schematic representation of the process and the mechanisms involved, respectively. 


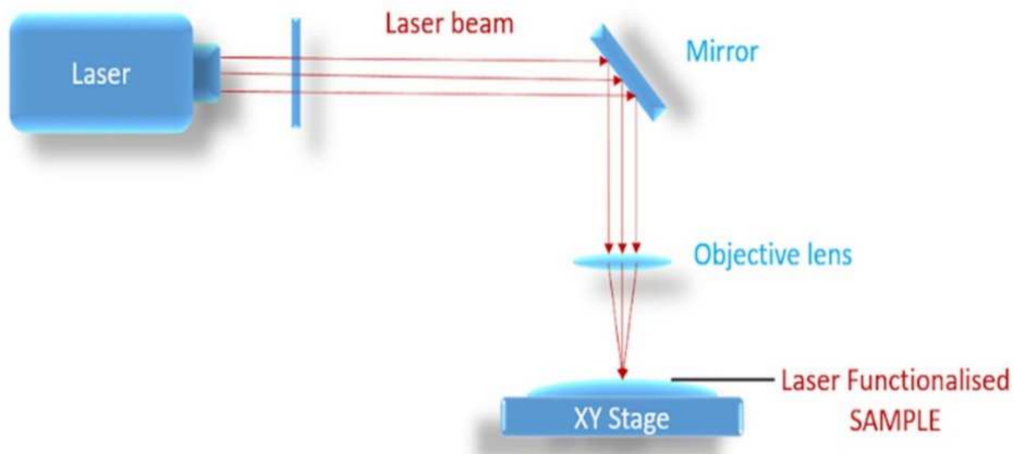

Figure 4. LDW schematic principle (Reproduced after [44]).
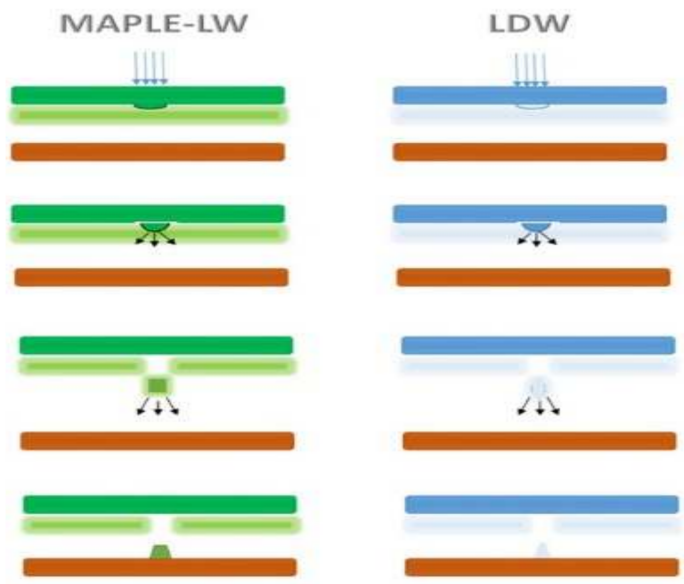

Figure 5. Schematic presentation of LDW mechanisms. (Left) In matrix-assisted pulsed laser evaporation direct-write (MAPLE-DW): the laser is absorbed by the matrix (not shown), which is removed after deposition. (Right) LDW printing of rheological systems: the thin layer absorbs the laser near the substrate and pushes the remaining ink forward (reproduced after [35]).

A direct transfer may also occur when using higher laser fluxes due to the vaporization process of the material in the thin layer. An undesirable effect is material vaporization, because its composition may be changed significantly, the shape of the transferred piece of material being no longer controllable. One may obtain a good transfer when the flux value doesn't suppress the ablation threshold and if the thickness of the layer is small enough $[45,46]$.

The advantages of the direct laser transfer technique are as follows:

- Vacuum or heating systems are not needed, the experiments being able to take place directly in the environment [35].

- It can be utilized on a large variety of targets [35].

- $\quad$ All kinds of substrates can be used [35].

- Almost every type of laser source is used, with pulse duration in the range of femtoseconds to nanoseconds [35].

- $\quad$ Geometric patterns can be obtained [47].

- $\quad 3 \mathrm{D}$ structures can be obtained by overlapping 2D modes. It can be achieved by successively exchanging numerous targets keeping the same substrate by modifying the composition of the samples [47].

Using laser direct writing technique, 2D and 3D structures can be obtained by directing the laser beam in the desired pattern over a surface region. Writing can be controlled by translating the laser and the target or by the target's rotation. Up to six degrees of freedom may be achieved (three axes of translation and rotation $(x, y$, and rotary)). Direct write rapid prototyping has several appealing advantages for medical device fabrication. A 
benefit of laser direct writing techniques over other manufacturing techniques, such as molding, is that devices with complex interior geometries can be fabricated to satisfy a given application's requirements (e.g., personalized medical implants, screws, etc.).

The contact between the surface region of a solid material and either a CW laser beam or a pulsed laser (PL) beam involves electronic excitation and electronic de-excitation [48-50]. The most important parameter in laser-material interaction is the laser wavelength, which can determine the absorption extent and laser radiation scattering in the material [49]. For example, concretely, absorption of the laser radiation by the material results in conversion of optical energy to heat within a narrow volume. The most important parameters of PL are the pulse energy (amount of energy in one laser pulse), the repetition rate, the fluence (amount of energy delivered to sample surface per unit area), pulse duration (duration of laser emission), the numerical aperture, the duration of laser exposure (time the laser is emitting radiation), the average power (total energy per unit time), and the peak power (pulse energy divided by pulse duration) [35]. For CW lasers, the notable parameters are the power (total energy per unit time), the duration of laser exposure (time the laser is emitting radiation), the irradiance (power per unit area), and the numerical aperture.

Photon absorption can lead to electron excitation in atoms and molecules of the target material. In the ablation process, energy transfer leads to an almost instantaneous release of the target material, either through thermal vaporization or photochemical interactions [36]. At lower energies, the bonds remain unbroken, and energy is converted into heat [51]. Therefore, localized heating of material results in sintering and/or melting. On the other hand, photopolymerization occurs when photoinitiator molecules absorb photons, and radicalized molecules, which can initiate polymerization reactions, are formed [52]. Several laser direct write techniques have been developed, which utilize these laser-target interactions. Some of these are presented in Table 2 [53].

Table 2. Laser-based direct-write techniques.

\begin{tabular}{ccccc}
\hline Method & Laser Type & Medical Applications & Compatible Biomaterials & Refs. \\
\hline $\begin{array}{c}\text { Selective laser } \\
\text { sintering/melting }\end{array}$ & CW, LP & $\begin{array}{c}\text { Tissue engineering; } \\
\text { biomedical devices; stents; } \\
\text { dental implants }\end{array}$ & $\begin{array}{c}\text { Ceramics; polymers; } \\
\text { metals }\end{array}$ & $\begin{array}{c}\text { Powder precursor; high } \\
\text { temperature; layered } \\
\text { fabrication }\end{array}$ \\
\hline Laser machining & CW, EX, LP, SP, USP & $\begin{array}{c}\text { Microfluidics; stents; } \\
\text { tissue engineering; } \\
\text { medical/dental implants }\end{array}$ & $\begin{array}{c}\text { Ceramics; polymers; } \\
\text { metals }\end{array}$ \\
\hline MAPLE direct-write & EX & $\begin{array}{c}\text { Drug delivery devices; } \\
\text { medical implants; cell } \\
\text { printing }\end{array}$ & $\begin{array}{c}\text { Ceramics; polymers; } \\
\text { metals; biomolecules }\end{array}$ & $\begin{array}{c}\text { Multiple processing } \\
\text { parameters; layered } \\
\text { fabrication }\end{array}$ \\
\hline Stereolithography & CW & $\begin{array}{c}\text { Medical augmented } \\
\text { reality; tissue engineering; } \\
\text { cell scaffolds }\end{array}$ & $\begin{array}{c}\text { Ceramic composites; } \\
\text { polymers; biomolecule } \\
\text { composites }\end{array}$ & Photopolymerization; \\
layered fabrication
\end{tabular}

LDW could prove ideal for printing viable cells (for tissue engineering, medical implants) and fast fabrication of paper-based microfluidic devices for various applications such as clinical diagnostics and analytical chemistry. Unlike other laser-based direct writing techniques, selective laser sintering (SLS) can print powder-type materials with a resolution in the order of $1 \mu \mathrm{m}$.

One could thus sinter a wide range of materials, including biometals, inaccessible via other techniques. SLS scaffolds demonstrate higher mechanical strength than those fabricated by other technologies.

On the other hand, safe cell patterning is impossible under high-power laser irradiation. Indeed, each cell should be printed via a gradient force generated by the near-infrared laser in a direct guided writing process [66].

In addition, a cell can be directed to a chosen location submitted to multiple lasers' irradiation. One, however, meets with difficulties to scale up this laser-guided direct writing (LGDW) technique to generate complete 3D structures. It is because cells are implanted into biological gel layers with a cell-by-cell transfer rate of only $2.5 \mathrm{cells} / \mathrm{min}$. The evaporation of a laser absorption layer (usually gold) or a cell with biopolymers was 
used via laser-transferring techniques [66]. LIFT, MAPLE-DW, and biological laser printing (BioLP) demonstrate a higher fabrication rate compared to LGDW, since they transfer biomaterial drops containing multiple cells. They can therefore be used to fabricate cellencapsulated 3D structures. The simplest "ribbon" is used in MAPLE-DW. Hydrogels are used to cover the ribbon, and then volatilized by the UV laser irradiation. MAPLE-DW secures a lower laser absorption rate than laser-induced forward transfer (LIFT) and BioLP.

LIFT was recently used to transfer biological materials onto collectors via evaporation of the laser absorption layer. The layer is sandwiched in-between the transparent quartz substrate and suspended-cell biomaterial layer in BioLP. Biomaterial and cells are transferred onto the substrate once a cell-containing matrix is volatilized. Stereolithography was utilized to generate 3D scaffolds as well as 3D cell-laden structures [66]. The process, particularly 2PP, can reach submicron or nanometer resolution in case of 3D scaffolds. On the other hand, the resolution remains limited due to the cell size in the case of stereolithography in bioprinting. Stereolithography, in comparison to other technologies, can aid in the elucidation of complicated geometries. It allows for a fast fabrication pace, creating hydrogel designs layer by layer (1 layer every 20-35 s) via DMD [66].

\subsection{Matrix-Assisted Pulsed Laser Evaporation (MAPLE) and C-MAPLE}

Laser ablation is a powerful and promising technique [67] for a wide range of applications, from biomedicine (tissue excision) [68], to characterization of biomaterials in analytical chemistry (assisted-matrix laser desorption ionization, MALDI) $[69,70]$ and the structuring of polymers in the field of microelectronics [67], in addition to the preservation of works of art [71].

Recently, much attention has been given to laser ablation of "delicate" organic materials. The recent progress in this area is generated by the evolution of composite thin film applications from controlled drug delivery systems, biosensors, advanced coatings for medical implants [72,73], or biological materials. This field has been pushed forward by the progress of laser sources, the evolution of "smart targets," and new applications in key technological fields, such as chemical, biological, and medical, at micro and nano scale. To better describe the interaction of the radiation with organic/biological materials, simple or protected by a matrix, complementary techniques were used, and simulated models were created [72].

The medical sector's requirements to obtain functionalized products involve the synthesis of high-quality films from complex substances and/or very fragile chemical compositions from a functional point of view. The conventional pulsed laser deposition (PLD) technique could not fulfill some of these requirements due to the high temperatures involved in the laser ablation process. This parameter considerably restricts the area of deposited materials. For medical purposes, alternative wet plasma depositions were proposed in the literature [74]. Research was focused on the selection of the best experimental conditions for deposition of film ions containing stoichiometric and crystallin hydroxyapatite (HA), the major component of human bone (55\%-65\%, according to sex and age) [74] Biological apatite was found to be a Ca-deficient amorph-crystalline and multi-substituted material. Studies were consequently focused to the development of substituted HA, glass (BG), and glass-ceramic (BGC) bioactive materials to valorize the biological relevance of foreign ions and crystallinity [75].

The MAPLE technique is analogous to the analytical technique of matrix-assisted Laser desorption/ionization mass spectrometry (MALDI-MS). MALDI-MS is a malleable (fine) ionization technique that allows the deposition and ionization of diverse molecular species $(\approx 10-1000 \mathrm{kDa})$. This process has been specially created to study large organic molecules and polymeric materials to accurately determine their molecular weight distribution [76].

To meet the challenge of depositing organic/polymeric materials with minimal thermal or chemical decomposition, "matrix-assisted pulsed laser evaporation" (MAPLE) was introduced to develop the PLD method. For this reason, in MAPLE, the biomolecules/polymers are dissolved in a solvent while the target is kept frozen during irradiation [72]. Consider- 
ing that the laser energy is mainly absorbed by the solvent/matrix and not by the polymer, the powerful action of laser interaction can be significantly reduced (without irreversible photochemical changes on the polymer). By analogy with the MALDI technology, the idea of minimizing the powerful action of the laser in contact with the biomaterial was presented [77]. Dissolving the biopolymer in an organic crystal matrix, the laser-induced ejection of the biopolymer suffers minimal fragmentation, allowing for mass spectroscopic characterizations. For chemical considerations, the frame of the MALDI technique cannot be applied in MAPLE because it is too complex. Instead of being directed in a mass spectrometer, the organic molecules in MAPLE are collected on a substrate, where the film grows instead of being directed ionized.

Concretely, the MAPLE surface functionalization implies the following steps:

- First, the "delicate" substance is dissolved in a solvent.

- After dissolution, the second step is to freeze the obtained mixture.

- After that, the frozen target is exposed to laser radiation.

- The material of interest is transferred while the frozen solvent protects it.

- During the process, the ice melts progressively, and the vacuum pump system evacuates the evaporated solvent. At the same time, the material of interest is deposited undamaged as a thin film onto the substrate [72].

One can find depicted in Figure 6 the general scheme of a MAPLE set-up together with the fundamental physico-chemical processes involved in the frozen target ablation.

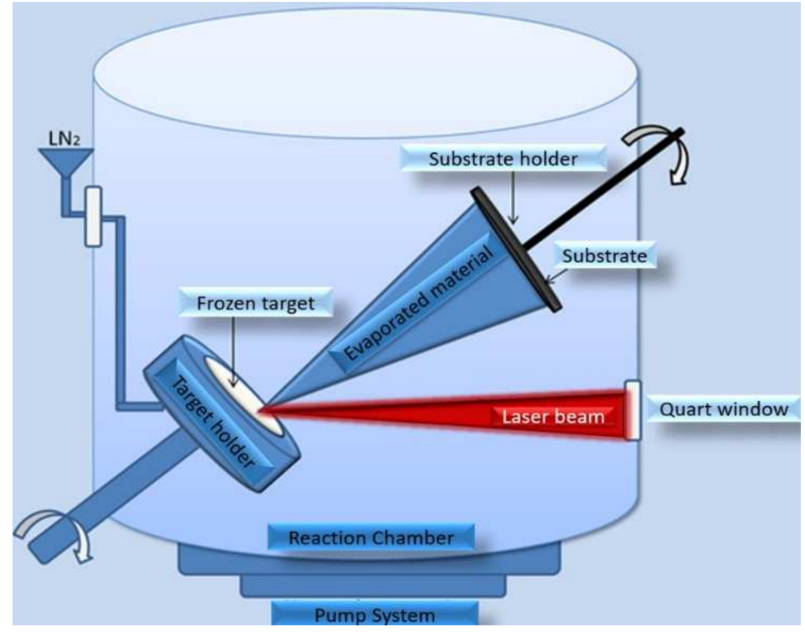

(a)

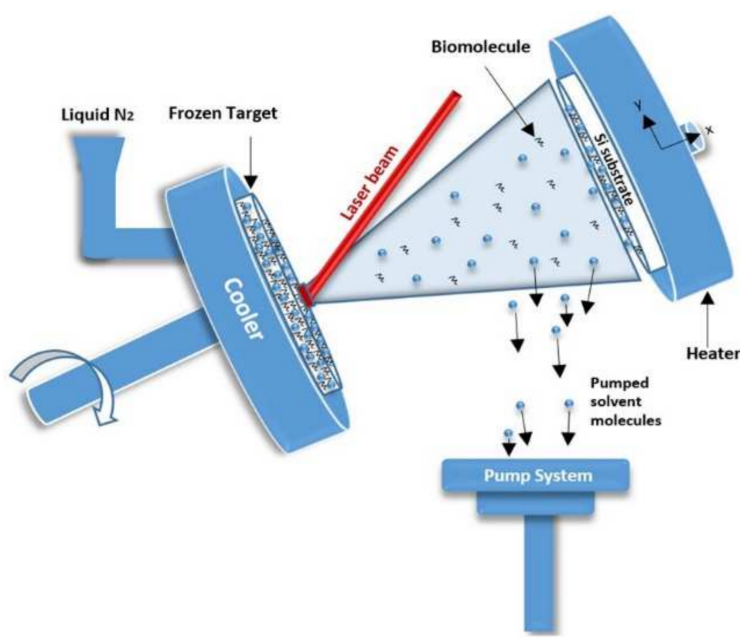

(b)

Figure 6. Schematic representation of (a) MAPLE system and (b) fundamental physico-chemical processes in MAPLE (reproduced from [72,78]).

MAPLE overcomes the constraints encountered in other solvent-based thin film synthesis technologies (e.g., irreversible decomposition, partial modification or destruction of organic substances), as well as inhomogeneity or difficulty in controlling the thickness [72].

A simple photothermal mechanism [38] has been suggested to describe the process (as specified by the term "evaporation" in the acronym MAPLE). Specifically, in the MAPLE process (Figure 6a), the photon energy is absorbed by the solvent matrix and converted into thermal energy, which causes the vaporization of the solvent [79]. While the solvent molecules from the target are evaporated, solute molecules (organic substances, biopolymers) approach the target-gas interface [79]. Therefore, due to the collective collisions with the vaporized solvent molecule, solute molecules gain enough kinetic energy to be transferred to the substrate in the gas phase [79].

The substrate and the target frozen in liquid $\mathrm{N}_{2}$ are placed inside a vacuum chamber, in which the whole deposition process takes place and fixes on specific supports. Because of the target support structure (double walls) compared with one of the substrates, liquid 
nitrogen can pass through and keep the target frozen. To obtain a better film morphology and to ensure uniform "erosion" of the target surface, it is necessary to permanently rotate the two supports throughout the entire operation of thin film deposition.

The quality of the obtained deposition is mostly influenced by the laser parameters (wavelength, fluency, pulse duration) [78]. Studies revealed that one might get the best results using relatively volatile matrices with low homogeneous dispersed/dissolved polymer [80]. As a result, the thin film growth is influenced by the nature of the organic compounds. Therefore, the choice of the matrix is the most important parameter that has to be taken into consideration when using the MAPLE technique.

Next, we will present the MAPLE target preparation steps.

The material of interest (active substance) is dissolved into a solvent (matrix) in the first phase. The organic compounds usually have a very high effective cross-section on UV absorption. The interaction of these molecules with UV photons is minimized, and a low concentration solution, in the range of $0.1 \%-5 \%$, is obtained [81].

The resulting solution is frozen in liquid nitrogen to obtain the MAPLE target (Figure 7) and maintained at low temperatures during deposition by a cooling device (cooler).

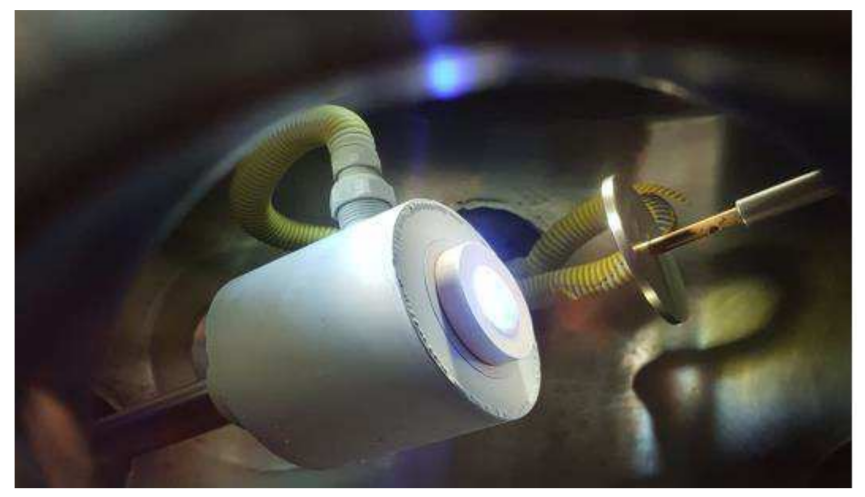

Figure 7. Representative MAPLE frozen target.

Besides laser parameters, another key role in MAPLE is represented by the choice of solvent; the target concentration must always be less than $5 \%$. This way, each molecule evaporated from the target is protected by multiple matrix molecules. Therefore, the thermal damage of polymer or biomaterial molecules during laser deposition is avoided. As a result, the solvent molecules absorb the laser energy released from the frozen target surface [79].

The conditions that the solvent must fulfill to obtain an efficient deposition are as follows: high freezing point; able to absorb the laser wavelength; high vapor pressure and volatility at RT (room temperature); not chemically active on laser exposure. It is necessary that the active material should have good solubility in the chosen solvent. The volatile solvent that does not reach the film is gradually evacuated during deposition by the pumping system.

Even though the vacuum in the chamber is at the beginning $10^{-3} \mathrm{~Pa}\left(10^{-5}\right.$ torr $)$, due to desorption caused by laser irradiation, the vacuum can reach up to $10^{-2} \mathrm{~Pa}$ [82]. The pressure may also increase up to hundreds of mtorr due to the presence of inert or reactive working gases. The pressure in the chamber during deposition can increase up to several hundred mtorr. The volatile component of the matrix is removed by the pumping system, while the heavy molecules (volatile biomolecules) condense onto the substrate [81].

Excimer laser sources $\left(\mathrm{KrF}^{*}, \lambda=248 \mathrm{~nm}\right.$ and/or $\left.\mathrm{ArF}^{*}, \lambda=193 \mathrm{~nm}\right)$ usually have pulse durations between 10 to $30 \mathrm{~ns}$ and repetition rates from 1 to $20 \mathrm{~Hz}$, while the laser spot varies from 1 to $10 \mathrm{~mm}^{2}$. Of course, other lasers with wavelengths from VIZ to IR can be used. Depending on the material and the solvent, the laser flux onto the target can be adjusted in the range of $0.01-0.5 \mathrm{~J} / \mathrm{cm}^{2}[62,81]$. 
The adhesion is influenced by the choice of the substrate (ceramics, metals, polymers, and/or semiconductors), which have to be compatible with the biomolecules deposited. Substrates are kept at RT during deposition. Another option is to slightly warm the substrate to restructure the growing film.

Another factor affecting the efficiency of MAPLE deposition and the matrix structure is de-dispersion or solubility degree [83].

Three main mechanisms, considerably different in nature, that explain the material ejection, have been proposed as follows: photochemical, photomechanical processes, and phase explosion [84].

It seems that the best results obtained via MAPLE are due to a thermal mechanism [72] However, thermal desorption/evaporation may not be achieved if the energy absorbed is too low. In this case, it has been suggested that the reason for the ejection process is the photomechanical mechanism (spallation) [83]. For nanosecond excimer laser sources, this mechanism is most likely characteristic of thin films deposited on substrates with different acoustic waves [79]; thus, it is clear that this is not dominant when irradiating the frozen solid targets.

An explosive boiling model, based on molecular dynamics simulations (MD) and thermodynamic considerations, was also proposed [85]. MD simulations are based upon a "breathing spheres model" [86]. This model predicts that below the threshold fluence, desorption is molecular (consistent with surface vaporization), while above it, a massive ejection of the material takes place, usually in the form of clusters. From a thermodynamic point of view [86], the boiling point is prolonged and is not significant for ns to ms durations. While the laser fluency is increasing, the system is overheated until a violent boiling ("explosive boiling") takes place. As a result, the system is expulsed in a mix of gases and droplets. The "respiratory sphere" model is too simplistic to represent the complexity of the chemicals employed in MAPLE investigations, and the values utilized for a number of parameters (to reduce computation needs) deviate dramatically from those of real systems, according to a frequent viewpoint $[86,87]$.

Before developing MAPLE, researchers began investigating solid cryogenic targets to better understand the processes that occur during laser-organic interactions [88]. The logic behind this decision was that the simplest chemicals are required for the understanding of the mechanisms involved. Simple organic substances are usually gaseous or liquid at room temperature. Thus, van der Waals descriptions are utilized for solid state simulations of cryogenic solids, which are generated by the condensation of vapors of these compounds on low-temperature substrates. The photodesorption/ejection processes can be studied in depth due to the physico-chemical simplicity of these systems. Furthermore, the structure of condensed materials can be systematically altered, allowing for the evaluation of its impact on ejection processes. There's also a lot of information about the photophysics and chemistry of these substances. As a result, the mechanisms and effects involved in the ejection of cryogenic films may be precisely examined, allowing for a thorough examination of the MAPLE technique's mechanics. Nucleation and bubble development at the nanoscale are involved in explosive boiling. Bubble dynamics are crucial for understanding the thermodynamics and dynamics of condensed phases at the nanoscale [83].

Other researchers [83] performed a theoretical investigation in which they simulated the first stages of molecular ejection. They believe that after laser irradiation, organic molecules move due to both mechanical and thermal factors.

In the case of molecules, the bead-and-spring model is employed, and the breathing spheres model is used to simulate the laser excitation of the solid cryogenic target. The effects of laser parameters (pulse duration and fluency) on ejection processes and the integrity of organic molecules expelled from a cryogenic target are investigated. These simulations discovered that when the laser pulse is shorter, the organic molecules travel quicker. Cluster ejection happens when the laser flux surpasses the ablation threshold, and the molecule deposits are unfragmented during the ablation process. 
The authors of [89] focused on deposition settings on photothermal and photochemical molecular fragmentation, resulting in thin films with regulated thicknesses that are impossible to achieve using other chemical methods.

Dr. Rodica Cristescu [90,91] implemented the matrix-assisted pulsed laser evaporation (MAPLE) (a physical-vapor deposition method patented by Robert A. McGill and Douglas B. Chrisey in 2000 in the USA) for the first time both in Romania (2002-2003) and Czech Republic (2005). Several investigations conducted in our lab have demonstrated that good results can be obtained for volatile matrices containing modest levels of organic chemicals [85,92]. MAPLE thin films of pullulan frozen from a $2 \mathrm{wt} \%$ biopolymer in dimethyl sulfoxide target were synthetized by Cristescu et al. [93]. The aim was to improve MSC retention of a damaged cartilage surface via boosting MSC therapeutic efficiency and functioning as a cellular adhesive. Thin films were optimized via adjusting the deposition parameters: solvent type and concentration, laser wavelength and frequency repetition rate, and ambient gas nature and pressure [69].

The films of FN and VN have been shown to promote the efficient adhesion of cells to substrates [70].

C-MAPLE: Combinatorial MAPLE (C-MAPLE) was introduced first by Sima et al. [94] in 2012 in order to fabricate coatings with compositional gradients on large substrate areas (several $\mathrm{cm}$ ) in a single-step process. The method is an extension of combinatorial-PLD (C-PLD), introduced initially by Takeuchi et al. [95], who managed to fabricate inorganic compositional library thin films. C-PLD experiments that generate inorganic bioactive coatings with a gradient of composition for tissue engineering have been reported [96,97]. Socol et al. [96] have shown the possibility of controlling the composition and surface morphology characteristics in the case of Ag-doped CaP thin films by using C-PLD. Next, the same group deposited antimicrobial libraries of Ag-doped carbon thin films to be used as coatings that minimize the risk of implant-associated infections [97,98]. Sima et al. [98] applied combinatorial MAPLE (C-MAPLE) to blend polymers in a thin film configuration with variable composition.

Combinatorial pulsed laser deposition (C-PLD) [99] influenced the creative design of the C-MAPLE method. C-MAPLE enables the production of thin films from the combination of two organic components, as well as the determination of the ideal dosage in the deposited structures. The C-MAPLE experiments are unique in that they use a concentric copper support [98]. Figure 8 depicts the general scheme of the C-MAPLE deposition process.
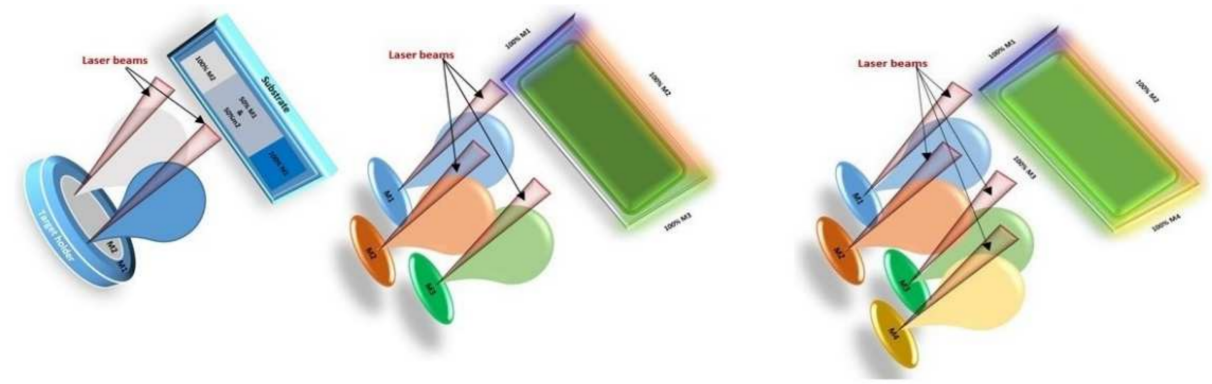

Figure 8. Experimental configuration for obtaining C-MAPLE thin films using two, three, or four targets (reproduced after $[19,20]$ ).

Combinatorial MAPLE experiments are unique because they use a ring-like concentric copper holder, which has also been proven to be highly effective for polymer bilayer structures created using a single-step MAPLE [94].

An optical splitter separated a $\operatorname{KrF}^{*}$ excimer laser beam $(\lambda=248 \mathrm{~nm}, \tau=25 \mathrm{~ns})$ into two beams. The beam splitter was positioned at 45 degrees in front of the incident laser beam, allowing one beam to pass through (Beam 1) and the other to diverge 90 degrees off its path (Beam 2). A mirror is placed next to the splitter to reflect Beam 2 in the same direction as Beam 1 and parallel to it. As a result, lenses focus the two beams, directing the two laser 
spots to the surfaces of the two concentric cryogenic targets. Because two focusing lenses are utilized individually, the laser set-up enables easy optimization of the laser fluence. This is a significant advantage because the two different solvents are vaporized using the same laser beam [100,101]. The laser beam is split into two beams that irradiate the frozen targets at the same time, vaporizing the materials and depositing them on a facing substrate [94].

We compiled in Table 3 a list of notable examples of biomaterials deposited onto different substrates for medical purposes utilizing the MAPLE and C-MAPLE procedures.

Table 3. Examples of biomaterials applied in surface functionalization with MAPLE and CMAPLE techniques.

\begin{tabular}{|c|c|c|c|c|c|c|}
\hline Method & Laser Type & Material & Solvent & Support & Applications & Refs. \\
\hline \multirow[b]{2}{*}{ MAPLE } & Excimer & $\begin{array}{c}\text { Graphene oxide nano-colloids; } \\
\text { hybrid BG-biopolymer; } \\
\text { Ag; } \\
\text { conjugated polymer DPP-DTT. }\end{array}$ & $\begin{array}{l}\text { Water and BSA; } \\
\text { chloroform }\end{array}$ & $\begin{array}{l}\text { Si } \\
\text { Glass } \\
\text { Ti } \\
\text { ITO }\end{array}$ & $\begin{array}{c}\text { Drug delivery; } \\
\text { implant devices/ implant } \\
\text { infections prevention; } \\
\text { organic photovoltaic devices }\end{array}$ & {$[62,102-105]$} \\
\hline & Nd: YAG & $\begin{array}{l}\text { HA/Lactoferrin/polyethylene } \\
\text { glycol-polycaprolactone } \\
\text { copolymer; } \\
\text { GO powder; } \\
\text { graphene-NiO hybrid; } \\
\text { TEO-loaded nanocapsules; } \\
\text { IgG modified UCNPs }\end{array}$ & $\begin{array}{l}\text { Water and BSA; } \\
\text { chloroform }\end{array}$ & $\begin{array}{l}\text { Si } \\
\text { Glass } \\
\text { Ti } \\
\text { ITO }\end{array}$ & $\begin{array}{c}\text { Drug delivery; } \\
\text { implant devices/ implant } \\
\text { infections prevention; } \\
\text { organic photovoltaic devices }\end{array}$ & {$[62,102-104]$} \\
\hline C-MAPLE & Excimer & $\begin{array}{c}\text { Sulfated Halomonas levan, } \\
\text { chitosan; } \\
\text { strontium hydroxyapatite } \\
\text { zinc } \beta \text {-tricalcium phosphate, } \\
\text { biomimetic apatite }\end{array}$ & $\begin{array}{c}\text { DMSO, deionized } \\
\mathrm{H}_{2} \mathrm{O}\end{array}$ & $\begin{array}{c}\text { Glass } \\
\mathrm{Ti} \\
\mathrm{Si}\end{array}$ & $\begin{array}{l}\text { Biomedical coatings; } \\
\text { bone repair; } \\
\text { antimicrobial orthopedic } \\
\text { coatings }\end{array}$ & {$[20,106,107]$} \\
\hline
\end{tabular}

For MAPLE performed with excimer lasers, the set of parameters includes two wavelengths $(193,248 \mathrm{~nm})$, pulse durations of $10-30 \mathrm{~ns}$, frequency rates in the range of $5-10 \mathrm{~Hz}$, and fluences below $1 \mathrm{~J} / \mathrm{cm}^{2}$. When performed with $\mathrm{Nd}$ : YAG lasers, the typical wavelengths were 266,532 , and $1064 \mathrm{~nm}$, for pulse durations of 5-25 ns; frequency rates were in the range of 4-10 Hz; and fluencies were between 0.4 and $0.45 \mathrm{~J} / \mathrm{cm}^{2}$. The experiments for C-MAPLE were carried out only for the $248 \mathrm{~nm}$ wavelength and a pulse duration of $25 \mathrm{~ns}$, frequency rates between 10 and $15 \mathrm{~Hz}$, and fluencies in the range of $0.7-1.1 \mathrm{~J} / \mathrm{cm}^{2}$.

\subsection{Magnetron Sputtering}

The deposition of a film (layer) at a surface (substrate) as a result of the condensation of atoms removed from a solid target by bombardment with energetic ions is known as sputter deposition (or sputtering deposition) [108].

The parts of a typical magnetron sputtering coating device are substrate holder, target, power supplier, vacuum pump, working gas, electric coils, magnets, and cooling water. The magnetron sputtering coating equipment can produce coatings of pure metals, alloys, and compounds with thickness up to $5 \mu \mathrm{m}$ [109].

As a result of the momentum transfer from the incoming particle, sputtering occurs from the surface when an atom or ion collides with it. In contrast with other vapor phase techniques there is no material melting [110]. The principal aspects of the technique [109-111] with a focus on method advantages and disadvantages are summarized below in Table 4 . 
Table 4. Magnetron sputtering advantages/disadvantages summary.

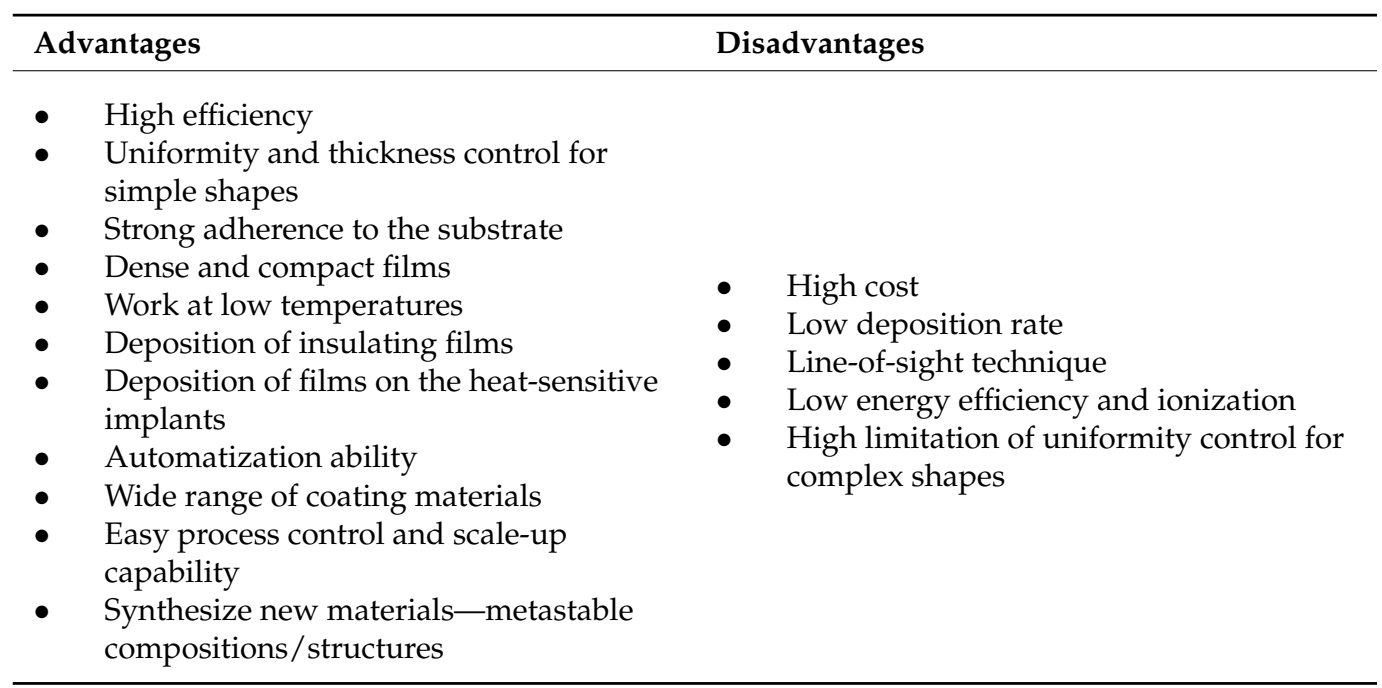

Even though there are many different variations of the sputtering process, they all share the same principle. The material to deposit, the target, the substrate, and the object to be deposited are placed in a sputtering chamber. The system is functional at low pressure, usually in the range of a few pascals, so the chamber has to be sealed and connected to the pumping system. To grow the film, the target must be bombarded with energetic particles. These particles set off a chain reaction of collisions between the atoms from the target. During these impacts, some target atoms receive enough kinetic energy to be ejected from the target or sputtered. The sputtering yield is the average number of sputtered particles per incident energetic particle. The sputtered atoms will then pass through the vacuum chamber and adhere to the substrate on which the film will grow [109].

When the sputtering gas is ionized, and an electric field accelerates the ions, particles with high energy are obtained. There are different techniques, such as direct current (DC) sputtering and radio frequency (RF) sputtering, to achieve this. Regarding the DC sputtering technique, a DC power supply is connected to the enclosure so that the target is kept at a negative voltage of around $1 \mathrm{kV}$, and the chamber is grounded. The substrate may also be electrically isolated, or it can be under a floating potential. An electric field exists due to the difference in potential between both target and chamber. It accelerates free charge carriers (electrons and ions) to tremendous kinetic energy, greater than the sputtering gas's ionization energy, only if they are accelerated for a sufficient distance without interacting. Because of their large size, ions have a higher chance of collision and reach a significantly lower kinetic energy than electrons. Therefore, the electrons mainly account for the ionization of the sputtering gas. During the ionization process of the sputtering gas, an electron is separated from its atom, and the number of free electrons increases. Due to the negative charge, the electrons will constantly be accelerated towards the chamber wall. Therefore, if an electron is coming close to the target, the number of electrons is increased, and it accelerates towards the chamber wall. Still, the newly created electrons will be formed closer and closer to the chamber wall. In the ionization process, additional electrons must be created close to the target to make it happen. It is accomplished by accelerating ions towards the target, as they will have a high possibility of creating new free electrons upon impact with the target. The ionization process can be self-sustained due to this effect [23].

Figure 9 presents the experimental setup of magnetron sputtering, showing the involved mechanisms inside. 


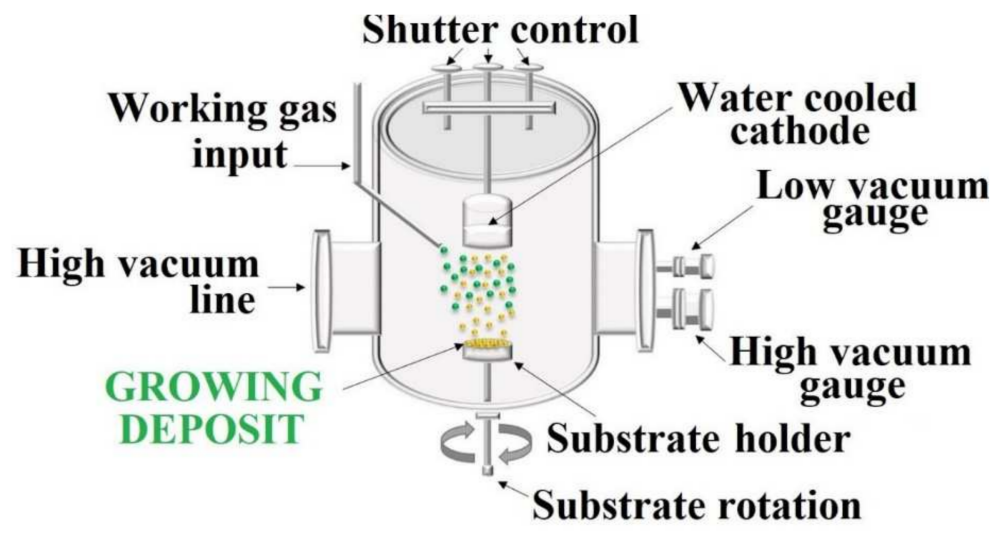

Figure 9. Inside mechanisms of magnetron sputtering [109].

In the following, we mention the applied steps for sputtering:

First, plasma produces ions that are directed to the target. Second, the ions sputter the atoms from the target. The expelled atoms are transferred to the substrate in the third step. Finally, atoms condense on the substrate and create a thin film.

During the magnetron sputtering process, a target that is supposed to be deposited on the substrate is bombarded with high-energy ions, such as He or Ar. When these highenergy ions collide with the target's surface, they transfer their energy and momentum to the atoms that already exist on the target's surface. The atoms that have gained momentum begin to vibrate and crash into the ones around them, resulting in cascades [111].

The atoms on the target material's outer surface are sputtered outward when they receive enough energy to break their bonds with nearby atoms. Through a super-clean environment created by the vacuum pump, the sputtered atoms travel toward the surface of the substrate that is placed on the substrate holder $[109,112,113]$.

Cluster beams can be created in a variety of ways. Surface erosion techniques such as arc discharge, magnetron sputtering, and laser vaporization are the most common. Magnetron sputtering is chosen in this study because of its excellent stability and flux, as well as its wide cluster size range.

Magnetron sputtering has proven excellent stability and flux and a wide cluster size range, from a single atom to nanoparticles with a diameter of $25 \mathrm{~nm}$. Even though magnetron sputtering has been employed for cluster creation since the early 1990s, there are still unanswered issues about cluster nucleation and growth mechanisms. The features of such sources are influenced by various factors, making it challenging to produce clusters with the correct composition and size.

The authors of [114] created a brand-new experimental setting. A commercial magnetron sputtering source, a home-built electrostatic quadrupole mass selector (QMS), and deposition capabilities in both an ultra-high vacuum (UHV) and a high vacuum (HV) chamber are important components. Because these qualities are of great practical value, the focus is on difficulties relating to effective beam steering and collimation, optimization of its intensity, and cluster size selection. The extreme pressure reduction of nearly eight orders of magnitude between the cluster locations is a unique problem.

Magnetron sputtering (PVDMS) has been used to fabricate Ca-P and ion-substituted Ca-P thin film coatings for orthopedic and dental implants. Biocompatibility and cellular response of ion-substituted Ca-P thin films depend on coating thickness, surface morphology, and crystal structure. The osseointegration of the implant with the host bone, and hence the implant's success, is determined by cell responses [39]. Strontium (Sr) was PLD coated on the surface of Ti implants via PVDMS for functionalization in form of Ti-Sr-O layers. Due to Sr presence, the functionalized biological coating demonstrated specific osseoinductivity benefits [115]. 
Magnetron sputtering proved to be a promising technology for producing biocompatible ceramic coatings based on Ca-P. Desired thin films can be thus deposited via selecting suitable deposition conditions.

Ca-P coating implants were bioactive, both in growth and remodeling in vitro/in vivo applications [115].

The small weight percent of silicon to HA has improved the primary reaction between bone tissue and HA. The development should be mentioned of co-RF and pulsed DC magnetron sputtering methods to manufacture Si-HA thin films with a high content of Si (from 1.8 to $13.4 \mathrm{wt}$ \%, one of the highest reported in the literature to date). Deposited films were amorphous and could crystallize under certain annealing temperatures only. They depend on silicon concentration and energy surface profiles, destabilizing the film's composition/structure. The Si replacement after annealing, higher than previously reported, can be accounted for by the higher Si concentration inside the HA lattice.

In vitro biological response was investigated using human osteoblast cells. Cells prefer HA to Si-HA surfaces, probably due to increased surface solubility, which inhibited protein-mediated cell attachment. The magnitude impact is dependent on the magnetron fabricated film's crystallinity and the silicon content [116].

A commercially available source (NC200U from Oxford Applied Research) creates the cluster. Material is sputtered into an aggregation zone in a DC magnetron, where clusters are made and then expanded into the source chamber by a nozzle. A two-inch conducting target with a thickness of up to $6 \mathrm{~mm}$ is employed for sputtering. A linear translator can adjust the distance between the front of the magnetron gun and the nozzle in the range of 5-100 mm, allowing the cluster size and beam intensity to be fine-tuned. The diameter of the nozzle orifice, which may be adjusted from 1 to $5 \mathrm{~mm}$ to improve the expansion process, is a crucial parameter. Two gas flow controllers control the flow of sputter and aggregation gases (Ar and $\mathrm{He}$ ) into the source. An independent gas capacitive manometer is utilized to measure the pressure in the aggregation tube. The typical operating pressure is a few millibars [114].

Table 5 compiles the significant examples of biomaterials deposited using the magnetron sputtering techniques.

Table 5. Significant examples of biomaterials deposited using the magnetron sputtering techniques.

\begin{tabular}{|c|c|c|c|c|c|c|c|}
\hline $\begin{array}{c}\text { Types of } \\
\text { Sputtering }\end{array}$ & Power & Base Pressure & Working Pressure & Target & Substrate & Applications & Refs. \\
\hline With Ions & $\begin{array}{l}3-25 \mathrm{~W} / \mathrm{cm}^{2} ; 3000 \\
\mathrm{~W} ; 2000 \mathrm{~W} ; 100 \mathrm{~V} \\
700-1100 \mathrm{~V}\end{array}$ & $5 \times 10^{-4} \mathrm{~Pa}$ & $\begin{array}{c}0.3 \mathrm{~Pa} ; 1-3 \\
\text { mTorr; } 8.3 \times 10^{-3} \\
\text { mbar }\end{array}$ & $\mathrm{Cr} ; \mathrm{C} ; \mathrm{Ti} ; \mathrm{Nb}$ & $\begin{array}{c}\text { Si; bioinert } \\
\text { PEEK; CoCrMo }\end{array}$ & $\begin{array}{l}\text { Medical stents; } \\
\text { medical implants }\end{array}$ & [117-119] \\
\hline $\begin{array}{l}\text { Pressure in the } \\
\text { chamber }\end{array}$ & $240 \mathrm{~W} ; 290 \mathrm{~W}$ & - & $0.3 \mathrm{~Pa} ; 40 \mathrm{~Pa}$; & $\mathrm{Ti}$ & $\mathrm{Ti}$ & $\begin{array}{l}\text { Medical/Dental } \\
\text { implants }\end{array}$ & [120] \\
\hline $\begin{array}{c}\text { Discharge in DC } \\
\text { or RF }\end{array}$ & $\begin{array}{l}\text { 75-100 W; } 200 \mathrm{~W} ; \\
\text { 10-80 W; }\end{array}$ & $\begin{array}{c}5 \times 10^{-6} \text { mbar; } 4 \\
\times 10^{-7} \\
\text { Torr }\end{array}$ & $\begin{array}{l}11.2 \text { m Torr; } 0.6 \mathrm{~Pa} \text {; } \\
5 \text { mTorr; } 10 \text { mTorr }\end{array}$ & $\begin{array}{c}\mathrm{Zr}-\mathrm{Al}-\mathrm{N} ; \mathrm{Si} ; \mathrm{B}_{4} \mathrm{C} \\
\mathrm{Ti}\end{array}$ & $\mathrm{Al} ; \mathrm{Ti}_{6} \mathrm{Al}_{7} \mathrm{Nb}$ & $\begin{array}{l}\text { tribological; } \\
\text { medical } \\
\text { implants; } \\
\text { infection } \\
\text { prevention }\end{array}$ & [121-123] \\
\hline
\end{tabular}

A significant time lag of innovative technological solutions for the functionalization of osseous implants follows from the ever-demanding healthcare requirements, for example, controlled release of therapeutic ions, match of biomaterial degradation-bone growth rates or antimicrobial efficiency. Applications of bioglass (BG) thin films in view of biofunctionalization of metal surfaces have been regarded as an optimal solution for surpassing their limited bulk mechanical properties. G.E. Stan et al. studied MS deposition of alkalifree BG thin films for various target-to-substrate working distances, which proved essential to synthesized suitable films [124].

Phosphate bio-glasses (PBGs) have demonstrated an ability to stimulate specific biological responses from tissue to molecular level via coupling bioactive and resorbable material properties. Tite et al. explored the radio-frequency magnetron-sputtered PBGs as sacrificial resorbable layers for prospective biomedical implant design [125]. 
MS versatility was demonstrated by A.C. Popa et al., who showed that biomimetic thin films' features (e.g., composition, structure, bonding strength, hardness, elastic modulus, and biological response) could be easily monitored by tuning the MS working conditions [126].

B.W. Stuart et al. showed that Ag/Ga could be combined into resorbable orthopedic phosphate bioactive glass (PBG, containing $\mathrm{P}, \mathrm{Ca}, \mathrm{Mg}, \mathrm{Na}$, and $\mathrm{Fe}$ ) thin films able to inhibit the growth of Staphylococcus aureus and Escherichia coli strains after implantation [127].

A series of seven alkali-free silica-based bioactive glasses (SBG) with $\mathrm{ZnO}$ and / or SrO additives (in the concentration of $0-12 \mathrm{~mol}$ percent) were prepared via melt-quenching. The aim was to fabricate a new candidate formulation with a coefficient of thermal expansion (CTE) similar to $\mathrm{Ti}$ and alloys, crucial for developing mechanically adherent implant types [128].

\subsection{D Bioprinting}

3D printing processes (e.g., inkjet printing, extrusion, solenoid, and fuse-deposition modeling) are revolutionizing the way to design, produce, and use many components, both in polymer and in metal, for applications in industry and everyday life.

By PVD technology, it is possible to quickly print 3D parts (based on customized designs) of composites, polymers, and metals (titanium, stainless steel, aluminum alloys, nickel super alloys, etc.).

It is amazing to learn about the history of 3D printing technology. Kodoma was the first to build a three-dimensional object that employed ultraviolet (UV) radiation to harden polymers and create solid structures in 1981. In 1984, Charles Hull invented stereolithography, which ushered in the era of 3D bioprinting (ISO/ASTM 52900:2015) [129]. The approach required employing a UV laser beam to create a real object from computer models [130,131].

Chuck Hull filed a patent for a stereolithographic process [130], attracting the world's attention and ushering in a period of rapid 3D printing growth. However, the term “3D printing" was coined later, and it originally related to MIT's powder bed adhesive jetting technology [132]. Fused deposition modeling (FDM), electron beam melting (EBM), selective laser sintering (SLS), direct ink writing (DIW), selective laser melting (SLM), stereolithography (SLA), inkjet 3D bioprinting (3DP), and other printing technologies are now commonly referred to as 3D printing by consumers and the media $[133,134]$. Another phrase that is more commonly used is additive manufacturing. Industrial end-use part makers, machine manufacturers, and global technical standards groups use a different word for additive manufacturing. All printing techniques, including 3D bioprinting and additive manufacturing, have the common feature of sequential layer-by-layer material addition under computer control [132].

The first medical application of this method occurred in early 2000, when seven patients received a tissue-engineered bladder made from autologous stem cells sown into a collagen scaffold [134]. Since then, the use of 3D technology in healthcare has increased dramatically.

Otorhinolaryngology has always been a trailblazer in adopting new technology, and $3 \mathrm{D}$ bioprinting has now made its way into this field, opening up new possibilities in patient care [130].

Organ transplant donor shortages are a major clinical issue around the world. Complications, subsequent injuries, and a lack of donor sources are potential dangers associated with older techniques. Three-dimensional (3D) printing technology can address these issues; it can be used to create personalized tissue engineering scaffolds quickly, repair tissue abnormalities in situ with cells, and even print tissue and organs directly.

Printed implants and organs can feature tailored material microstructures and cell layouts to stimulate cell proliferation and differentiation, in addition to flawlessly matching the patient's injured tissue. As a result, such implants enable the needed tissue restoration and may one day overcome the donor scarcity problem [135]. 
Three-dimensional (3D) bioprinting, also known as additive manufacturing (AM), creates an object from 3D digital models through layer-by-layer deposition of material. Fused deposition modelling (FDM) is a popular method for making 3D things using a melted filament deposited in layers [136].

For more than three decades, 3D bioprinting has been widely used in business and manufacturing. Its application in the medical field is new, but it has a lot of potential in medical education, surgery planning, and custom prosthesis manufacture [130].

Additive manufacturing is a process that involves layering material to make a threedimensional object (in opposition to removing material from a block). It is a layer-by-layer material-joining procedure for creating objects from 3D model data.

This is one of the primary components of Industry 4.0, in which industrial operations are carried out utilizing smart technologies such as cloud computing, cybersecurity, big data analytics, autonomous systems, simulation, and system integration, among other things [137]. In the design and development of diverse 3D components, there are numerous types of state-of-the-art additive manufacturing and methodologies (Figure 10). Using CAD software, different components may be created, and then 3D printers can be used to build the components. Polymer, composites, metal, functionally graded materials, ceramic, and so on are common materials for 3D deposition, and they can be in sheet, filament, powder, or liquid form. Direct energy deposition, binder jetting, powder bed fusion, material jetting, material extrusion, vat polymerization, and sheet lamination can all be used to make 3D objects. Support removal, surface polishing, defect elimination, and destructive/non-destructive testing are all examples of post-processing for produced parts. Tooling components, biological implants, production parts, devices, artificial organs, and structures are just a few of the 3D-printed objects that may be fabricated with additive manufacturing. The main impediment to this technology's adoption is a lack of understanding of how it works and how it fits into the design and development process [138-141].
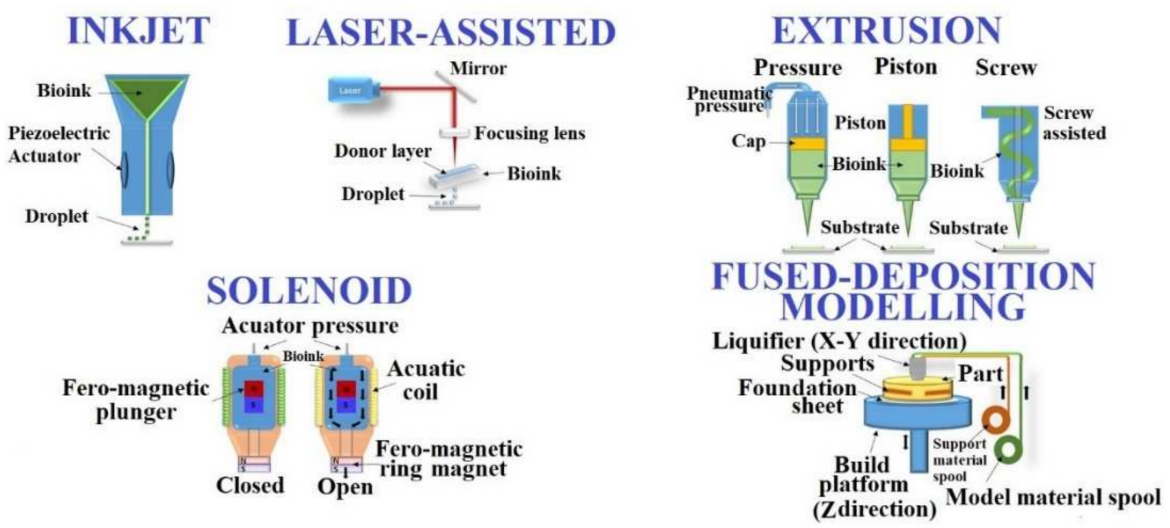

Figure 10. Examples of bioprinting techniques (reproduced after [139]).

The input energy-powder interaction and the consolidation mechanism are commonly used to classify AM techniques. The most often utilized AM processes for achieving high densification include selective laser melting (SLM), electron beam melting (EBM), selective laser sintering (SLS), and laser engineered net shaping (LENS) [142,143]. Table 6 provides an overview of AM processes for metals, polymers, and ceramic materials with powder as the feedstock [134]. Powder bed fusion procedures are the name given to these techniques [144]. 
Table 6. Classification of AM methods (from different types of feedstocks: metals, ceramics, polymers) [144].

\begin{tabular}{ccc}
\hline Deposition Type & Mechanism & Technique \\
\hline & Using electron beam & Electron beam melting (EBM) \\
Powder bed fusion & Using laser & Selective laser sintering (SLS) \\
& Via binder & Selective laser melting (SLM) \\
& Via binder & Binder Jetting (BJ) \\
\hline Coaxial laser deposition & Laser metal deposition & Laser metal deposition (LMD) \\
\hline
\end{tabular}

The procedure (Figure 11) begins with creating a 3D digital design using CAD software, followed by the conversion of the design to a standard triangle language (STL) file and the transfer of data to the printer [138-145]. The object is created through layered deposition of material on a mobile platform, with the material hardening as it cools [130].

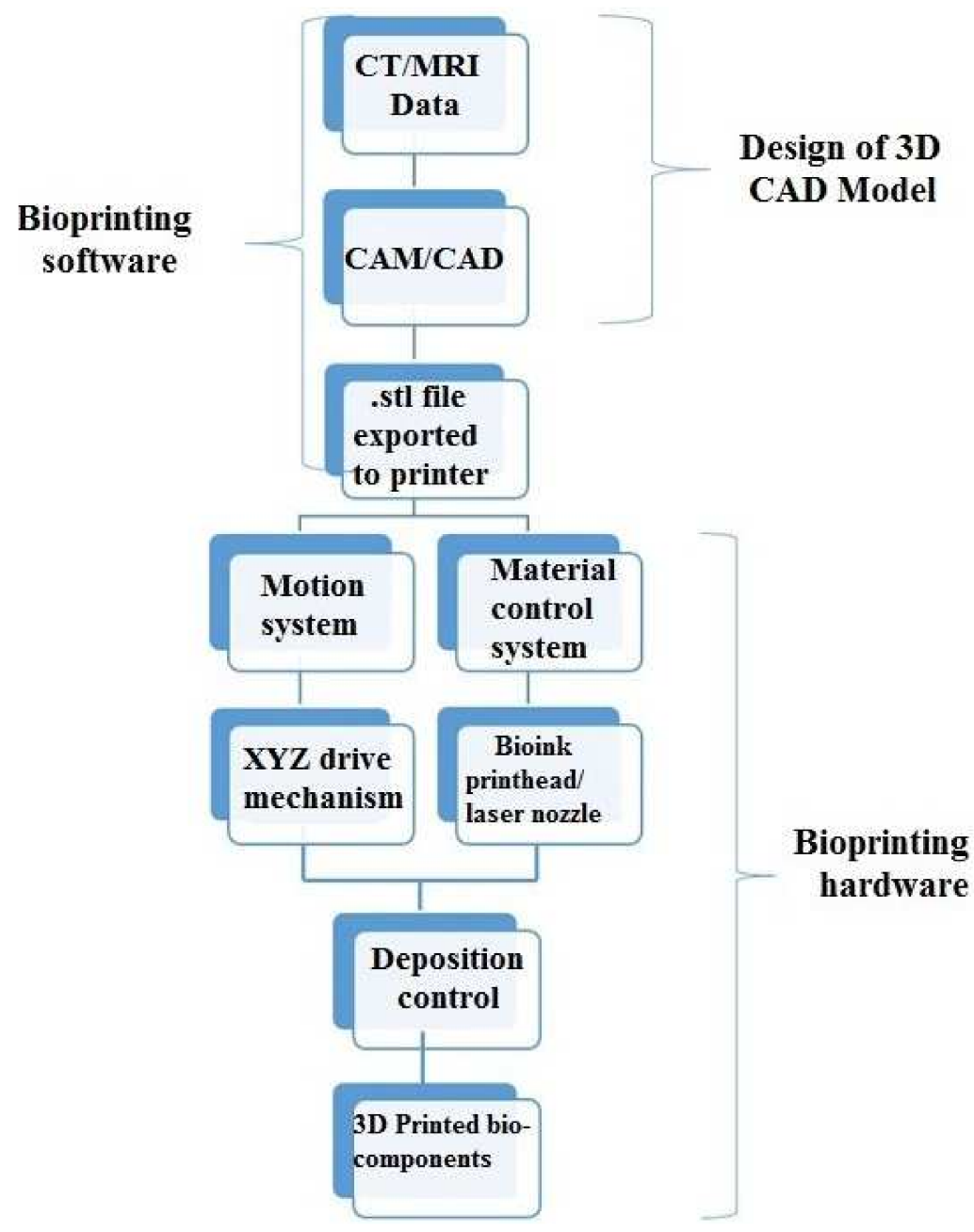

Figure 11. A technical route for 3D bioprinting [140].

These days, ceramic implants, particularly those of calcium phosphates (mostly HA), that promote close contact with the natural bone are notably emerging. Copper ion addition to bio-ceramics is predicted to improve the biocompatibility of bone graft substitutes. Previous research has shown that copper-doped HA (Cu-doped HA) can be synthesized by solid-state sintering of $\mathrm{HA}$ and $\mathrm{CuO}$ powders mixture at around $1100{ }^{\circ} \mathrm{C}$. Coppersubstituted HA was observed to be metastable during the sintering process, resulting in apatitic grains and $\mathrm{Cu}$-rich boundaries formation. The need for ultra-quick sintering is 
critical. Selective laser sintering (SLS) is an additive manufacturing technology that benefits from an ultra-fast sintering process under laser irradiation. The proper phase for the application of laser irradiation on polymer-ceramic or polymer-metal composites requires ceramic powder bed laser sintering (CPBLS). To achieve densification of $\mathrm{Cu}$-doped HA ceramics via a CPBLS process, one must control the powder bed composition/morphology/structure, as well as three other critical CPBLS parameters: (i) the laser beam energy, (ii) the laser power and scanning speed, and (iii) the distance between two successive laser lines [146].

Biomedical applications require materials with low modulus and stiffness for optimal implants that better match the elastic modulus of human bone while providing increased strength and wear resistance. The fabrication of parts with specific size and shape without joining or welding operations is desired, while also ensuring improved mechanical properties and greater resistance to environmental attack. Materials advancement and change of process conditions and parameters are mandatory to reach these requirements. Recent research was focused along these lines towards advanced or disruptive manufacturing pathways and proper alloy development (e.g., $\mathrm{Ti}, \mathrm{Al}$, steels, and so on) using additive manufacturing (AM) techniques for a variety of applications. Selective laser melting is the popular and preferred AM process for fabricating fully dense products in the requisite dimensions. AM Ti alloys are superior to others due to higher performances such as lightweight or good fatigue and corrosion resistance, which are achieved via microstructure changes due to quicker heating and cooling rates during laser printing. Ti alloys with a single (a) or dual (ab) microstructure are primarily used in the aviation and automobile industries. Due to the low Young modulus, they are similar to alloys intensively studied for human bone replacements in bio and dental implants. The adequate reinforcement addition of Ti-based materials to modify structures is, in our opinion, a reliable approach. Therefore, critical considerations for optimizing the processing parameters of SLM-manufactured Ti alloys and Ti matrix composites (TMCs) were reviewed. Future development of these materials is also critically examined [144].

The main difference between 3D bioprinting and 3D printing is represented by the materials used for deposition. As depicted in Table 7, the materials used for 3D bioprinting are organic, starting from bioactive glass and HA, up to gelatin, fibrin and hyaluronic acid. Meanwhile, 3D printing uses inorganic materials, like metal powders and alloys. This way, the 3D bioprinting technique can fabricate biocompatible depositions, while 3D printing is more focused on industrial engineering applications.

Table 7. Relevant examples of 3D bioprinting techniques and applications.

\begin{tabular}{|c|c|c|c|c|c|}
\hline Technique & $\begin{array}{l}\text { Mammalian Cell/Tissue } \\
\text { Types }\end{array}$ & Material & Limitations & Applications & Refs. \\
\hline Binder Jetting Method (BJM) & $\begin{array}{l}\text { Human osteoblast; bone } \\
\text { cells }\end{array}$ & $\begin{array}{l}\text { Bioactive glass; Tcp-Bg } \\
\text { composite; polyamide }\end{array}$ & $\begin{array}{l}\text { Lower mechanical } \\
\text { properties; rough details; } \\
\text { limited material selection }\end{array}$ & $\begin{array}{l}\text { Scaffolds; tissue } \\
\text { scaffolding and prosthetics }\end{array}$ & {$[147,148]$} \\
\hline Extrusion Bioprinting & Human osteosarcoma & $\begin{array}{l}\text { Pcl/Ha scaffold with } \\
\text { Ha-particle exposure }\end{array}$ & Distortion of cell structure & Bone tissue engineering & {$[149,150]$} \\
\hline Fused Deposition Modeling & $\begin{array}{l}\text { Septal nasal cartilage; } \\
\text { mouse osteoblasts; } \\
\text { osteosarcoma cells }\end{array}$ & PLLA; PLA; Ha & $\begin{array}{l}\text { Slow; medium print } \\
\text { quality; minor shrinking }\end{array}$ & Nasal implant; scaffolds & {$[124,141,151-154]$} \\
\hline Ink-Jet-Based Bioprinting & $\begin{array}{c}\text { NIH/3T3 (3T3) embryonic } \\
\text { murine fibroblastes; } \\
\text { DM03-Nscs; 3T3 cells; } \\
\text { bovine chondrocytes; } \\
\text { femur; Hs68 }\end{array}$ & $\begin{array}{l}\text { Alginate; collagen; culture } \\
\text { medial; hydrogels; } \\
\text { pluronic }\end{array}$ & $\begin{array}{c}\text { Lack of precision in } \\
\text { droplet placement and } \\
\text { size, need for low viscosity } \\
\text { bioink }\end{array}$ & $\begin{array}{l}\text { Tissue engineering; } \\
\text { biosensor microfabrication }\end{array}$ & [155-160] \\
\hline Pressure-Assisted Bioprinting & $\begin{array}{l}\text { Cartilage progenitor cells; } \\
\text { Hmscs; osteoblasts cells; } \\
\text { DF-N; endothelial cells; } \\
\text { Schwann cell }\end{array}$ & $\begin{array}{l}\text { Gelatin; alginate; chitosan; } \\
\text { fibrinogen; collagen; } \\
\text { hyaluronic acid }\end{array}$ & $\begin{array}{l}\text { Limited mechanical } \\
\text { stiffness; critical timing of } \\
\text { gelation time; specific } \\
\text { matching of the densities } \\
\text { of the material and the } \\
\text { liquid medium to preserve } \\
\text { shapes; low resolution and } \\
\text { viability }\end{array}$ & $\begin{array}{c}\text { Tissue engineering; } \\
\text { vascular engineering; } \\
\text { capillary network; tissue } \\
\text { regeneration }\end{array}$ & [161-167] \\
\hline Laser-Assisted Bioprinting & $\begin{array}{l}\text { Rat acinar cells; hCMPCs; } \\
\text { endothelial cells }\end{array}$ & Gelatin; matrigel & Time consuming, high cost & Tissue engineering & {$[64,167,168]$} \\
\hline Solenoid- Based Printing & $\begin{array}{l}\text { Murine NSC line; } \\
\text { keratinocytes and } \\
\text { fibroblasts }\end{array}$ & Fibrin; collagen & $\begin{array}{l}\text { High heat; } \\
\text { High inrush }\end{array}$ & $\begin{array}{l}\text { Neural tissue regeneration; } \\
\text { tissue engineering }\end{array}$ & {$[167,169,170]$} \\
\hline
\end{tabular}


Table 7 provides some valuable examples of 3D bioprinting techniques and applications.

Laser additive manufacturing technologies extended to medical/biological applications confer obvious advantages such as: (i) ability to tune and optimize physical and chemical abilities for complex structures fabrication; (ii) one-step full device fabrication capability via multimaterial printing technologies; (iii) device performance improvement for various applications due to hierarchical porosities; (iv) fabrication ability of nonmonolithic structures via localized features using multimaterial printing technologies; (v) device personalization for tissue engineering scaffolds, or wearable sensors [171].

We believe that bioprinting has enormous development potential in tissue and organ regeneration. In our opinion, 3D bioprinting will be crucial for the fabrication of functional tissues and organs for transplants or utilization as models in drug screening methods or physiological investigations. This could lead to a more personalized treatment of patients, (i.e., to a better clinical outcomes). In addition 3D bioprinting could facilitate the direct fabrication of end-use soft robots for biological applications, with sophisticated design and functions (e.g., via sensors printing onto smart materials) [172].

\section{Conclusions and Perspectives}

The medical device industries now seek advanced biomaterials for the next generation of functional layers with long-term reliability and high success rates.

Laser techniques demonstrated in this respect are less costly and grant high flexibility, high speed, and environment friendliness.

In this context, recent work is reviewed by the three major laser deposition techniques (PLD, LDW, MAPLE/C-MAPLE bioprinting) in comparison with some other performant alternatives (e.g., magnetron sputtering, 3D bioprinting, plasma spray, and dip coating). A high purity degree, non-contact micromachining, high-precision coherent beams, low processing costs of a wide range of biomaterials, reduced pollution, and high operating speeds are among the benefits of these laser techniques.

Details regarding advantages/disadvantages of each technique, set-up, materials, components, procedures, methods, and medical applications were comparatively examined.

Further efforts are needed to minimize/overcome difficulties associated with laser processing, such as reproducibility, microcracks, or heat-affected zones. Therefore, a fast integration of laser functionalization techniques is expected to support a novel utilization extension of these techniques in clinical and other biomedical applications.

Author Contributions: Conceptualization, M.B., A.I.V. and I.N.M.; methodology, A.I.V., M.B., N.M., S.A. and C.N.M.; software, A.I.V., M.B., N.M. and S.A.; validation, M.B., A.I.V. and C.N.M.; formal analysis, M.B., A.I.V., N.M. and S.A.; investigation, A.I.V., M.B., N.M., S.A. and C.N.M.; resources, A.I.V.; data curation, A.I.V., I.N.M. and C.N.M.; writing-original draft preparation, A.I.V. and M.B.; writing-review and editing, A.I.V., M.B., N.M., S.A. and C.N.M.; visualization, A.I.V. and I.N.M.; supervision, A.I.V., I.N.M. and C.N.M.; project administration, A.I.V. and C.N.M.; funding acquisition, A.I.V. and C.N.M. All authors have read and agreed to the published version of the manuscript.

Funding: A.I.V. acknowledges financial support from a grant of the Romanian Ministry of Education and Research, under Romanian National Nucleu Program LAPLAS VI-contract No. 16N/2019 CNCS-UEFISCDI and project number PN-III-P4-ID-PCE-2020-2273, within PNCDI III. I.N.M., M.B. and A.I.V. give thanks for the financial support from a grant of the Romanian Ministry of Education and Research, CNCS-UEFISCDI, project number PN-III-P4-ID-PCE-2020-2030 (PCE113/2021). N.M., S.A. and C.N.M. give thanks for the financial support from a grant of the Romanian Ministry of Education and Research, CNCS-UEFISCDI, project number ID code RO-NO-2019-0498 and UEFISCDI under the TE_196/2021. I.N.M. and M.B. acknowledge and give thanks the partial financial support of this work under the POC-G Contract No. 135/2016.

Institutional Review Board Statement: Not applicable.

Informed Consent Statement: Not applicable.

Data Availability Statement: Data sharing is not applicable to this article as no new data were created or analyzed in this study. 
Acknowledgments: A.I.V. acknowledges, with thanks, the financial support under the national fellowship program L'Oréal-UNESCO "For Women in Science".

Conflicts of Interest: The authors declare that there is no conflict of interest.

$\begin{array}{ll}\text { Abbreviations } \\ \text { AM } & \text { Additive manufacturing } \\ \text { MALDI } & \text { Assisted-matrix laser desorption ionization } \\ \text { AMSCs } & \text { Human amniotic membrane-derived mesenchymal stem cells } \\ \text { BMSCs } & \text { Bone marrow mesenchymal stem cells } \\ \text { BioLP } & \text { Biological laser printing } \\ \text { CVD } & \text { Chemical vapor deposition } \\ \text { CVD } & \text { Chemical vapor deposition and cold vapor deposition } \\ \text { C-MAPLE } & \text { Combinatorial-matrix-assisted pulsed laser evaporation technique } \\ \text { CW } & \text { Continuous wave } \\ \text { DIW } & \text { Direct ink writing } \\ \text { LD } & \text { Direct laser transfer } \\ \text { DDS } & \text { Drug delivery systems } \\ \text { ECM } & \text { Extracellular matrix } \\ \text { EBM } & \text { Electron beam melting } \\ \text { EX } & \text { Excimer } \\ \text { FDM } & \text { Fused deposition modeling } \\ \text { 3DP } & \text { Inkjet 3D bioprinting } \\ \text { LP } & \text { Long pulse } \\ \text { LENS } & \text { Laser engineered net shaping } \\ \text { LGDW } & \text { Laser-guided direct writing } \\ \text { LIFT } & \text { Laser induced forward transfer } \\ \text { LSPI } & \text { Laser surface plasma interaction } \\ \text { MAPLE } & \text { Matrix-assisted pulsed laser evaporation technique } \\ \text { MSCs } & \text { Mesenchymal stem cells } \\ \text { MD } & \text { Molecular dynamics } \\ \text { NILPRP } & \text { National Institute for Lasers, Plasma and Radiation Physics } \\ \text { PS } & \text { Plasma spraying } \\ \text { PVD } & \text { Physical vapor deposition } \\ \text { PLD } & \text { Pulsed LASER deposition } \\ \text { SLM } & \text { Selective laser melting } \\ \text { SLS } & \text { Selective laser sintering } \\ \text { SP } & \text { Short pulse } \\ \text { SLA } & \text { Stereolithography } \\ \text { RT } & \text { Room temperature } \\ \text { USP } & \text { Ultra-short pulse } \\ \text { VEGF } & \text { Vascular endothelial growth factor } \\ & \end{array}$

\section{References}

1. Liu, Y.; Rath, B.; Tingart, M.; Eschweiler, J. Role of implants surface modification in osseointegration: A systematic review. J. Biomed. Mater. Res. Part A 2020, 108, 470-484. [CrossRef]

2. Martin, P.M. Deposition technologies: An overview. In Handbook of Deposition Technologies for Films and Coatings; Elsevier Science: UK, 2010; Volume 3.

3. Seshan, K. Handbook of Thin Film Deposition Techniques Principles, Methods, Equipment and Applications, 2nd ed.; CRC Press: Boca Raton, FL, USA, 2002.

4. Abegunde, O.O.; Akinlabi, E.T.; Oladijo, O.P.; Akinlabi, S.; Ude, A.U. Overview of thin film deposition techniques. AIMS Mater. Sci. 2019, 6, 174-199. [CrossRef]

5. Venable, J. Introduction to Surface and Thin Film Process; Cambridge University Press: New York, NY, USA, 2000.

6. Li, P.; Chu, P. Thin film deposition technologies and processing of biomaterials. In Thin Film Coatings for Biomaterials and Biomedical Applications; Elsevier: Amsterdam, The Netherlands, 2016; pp. 3-28.

7. Bahuguna, G.; Mishra, N.K. Thin Film Coating. Res. J. Chem. 2016, 6, 65-72.

8. Khlyustova, A.; Cheng, Y.; Yang, R. Vapor-deposited functional polymer thin films in biological applications. J. Mater. Chem. B 2020, 8, 6588-6609. [CrossRef]

9. Cristescu, R.; Mihailescu, I.; Jelinek, M.; Chrisey, D. Functionalized thin films and structures obtained by novel laser processing issues. In Functional Properties of Nanostructured Materials; Springer: Berlin/Heidelberg, Germany, 2006; pp. 211-226. 
10. Linez-Bataillon, P.; Monchau, F.; Bigerelle, M.; Hildebrand, H. In vitro MC3T3 osteoblast adhesion with respect to surface roughness of Ti6Al4V substrates. Biomol. Eng. 2002, 19, 133-141. [CrossRef]

11. Aikhionbare, F.O.; Mayo, Z. Mitochondrial DNA sequences of greenbug (Homoptera: Aphididae) biotypes. Biomol. Eng. 2000, 16, 199-205. [CrossRef]

12. Hildebrand, H.; Blanchemain, N.; Mayer, G.; Chai, F.; Lefebvre, M.; Boschin, F. Surface coatings for biological activation and functionalization of medical devices. Surf. Coat. Technol. 2006, 200, 6318-6324. [CrossRef]

13. Zhang, Y.; Bataillon-Linez, P.; Huang, P.; Zhao, Y.; Han, Y.; Traisnel, M.; Xu, K.; Hildebrand, H. Surface analyses of micro-arc oxidized and hydrothermally treated titanium and effect on osteoblast behavior. J. Biomed. Mater. Res. Part A 2004, 68, 383-391. [CrossRef]

14. Tang, Z.; Xie, Y.; Yang, F.; Huang, Y.; Wang, C.; Dai, K.; Zheng, X.; Zhang, X. Porous tantalum coatings prepared by vacuum plasma spraying enhance bmscs osteogenic differentiation and bone regeneration in vitro and in vivo. PLoS ONE 2013, 8, e66263.

15. Feddes, B.; Wolke, J.; Vredenberg, A.; Jansen, J. Initial deposition of calcium phosphate ceramic on polyethylene and polydimethylsiloxane by rf magnetron sputtering deposition: The interface chemistry. Biomaterials 2004, 25, 633-639. [CrossRef]

16. Salou, L.; Hoornaert, A.; Louarn, G.; Layrolle, P. Enhanced osseointegration of titanium implants with nanostructured surfaces: An experimental study in rabbits. Acta Biomater. 2015, 11, 494-502. [CrossRef] [PubMed]

17. Hindy, A.; Farahmand, F.; sadat Tabatabaei, F. In vitro biological outcome of laser application for modification or processing of titanium dental implants. Lasers Med. Sci. 2017, 32, 1197-1206. [CrossRef] [PubMed]

18. Yuan, L.; Ding, S.; Wen, C. Additive manufacturing technology for porous metal implant applications and triple minimal surface structures: A review. Bioact. Mater. 2019, 4, 56-70. [CrossRef]

19. Axente, E.; Elena Sima, L.; Sima, F. Biomimetic coatings obtained by combinatorial laser technologies. Coatings 2020, 10, 463. [CrossRef]

20. Visan, A.; Stan, G.E.; Ristoscu, C.; Popescu-Pelin, G.; Sopronyi, M.; Besleaga, C.; Luculescu, C.; Chifiriuc, M.C.; Hussien, M.; Marsan, O. Combinatorial MAPLE deposition of antimicrobial orthopedic maps fabricated from chitosan and biomimetic apatite powders. Int. J. Pharm. 2016, 511, 505-515. [CrossRef] [PubMed]

21. Chioibasu, D.; Duta, L.; Popescu-Pelin, G.; Popa, N.; Milodin, N.; Iosub, S.; Balescu, L.M.; Catalin Galca, A.; Claudiu Popa, A.; Oktar, F.N. Animal origin bioactive hydroxyapatite thin films synthesized by RF-magnetron sputtering on 3D printed cranial implants. Metals 2019, 9, 1332. [CrossRef]

22. Sima, L.E.; Stan, G.E.; Morosanu, C.O.; Melinescu, A.; Ianculescu, A.; Melinte, R.; Neamtu, J.; Petrescu, S.M. Differentiation of mesenchymal stem cells onto highly adherent radio frequency-sputtered carbonated hydroxylapatite thin films. J. Biomed. Mater. Res. Part A 2010, 95, 1203-1214. [CrossRef]

23. Fernández-Pradas, J.M.; Serra, P. Laser-induced forward transfer: A method for printing functional inks. Crystals 2020, 10, 651. [CrossRef]

24. Adams, C.S.; Antoci Jr, V.; Harrison, G.; Patal, P.; Freeman, T.A.; Shapiro, I.M.; Parvizi, J.; Hickok, N.J.; Radin, S.; Ducheyne, P. Controlled release of vancomycin from thin sol-gel films on implant surfaces successfully controls osteomyelitis. J. Orthop. Res. 2009, 27, 701-709. [CrossRef]

25. Hall, D.J.; Urban, R.M.; Pourzal, R.; Turner, T.M.; Skipor, A.K.; Jacobs, J.J. Nanoscale surface modification by anodic oxidation increased bone ingrowth and reduced fibrous tissue in the porous coating of titanium-alloy femoral hip arthroplasty implants. J. Biomed. Mater. Res. Part B Appl. Biomater. 2017, 105, 283-290. [CrossRef]

26. Li, X.; Wang, L.; Yu, X.; Feng, Y.; Wang, C.; Yang, K.; Su, D. Tantalum coating on porous Ti6Al4V scaffold using chemical vapor deposition and preliminary biological evaluation. Mater. Sci. Eng. C 2013, 33, 2987-2994. [CrossRef]

27. Yao, Y.-t.; Liu, S.; Swain, M.V.; Zhang, X.-p.; Zhao, K.; Jian, Y.-t. Effects of acid-alkali treatment on bioactivity and osteoinduction of porous titanium: An in vitro study. Mater. Sci. Eng. C 2019, 94, 200-210. [CrossRef] [PubMed]

28. Jemat, A.; Ghazali, M.J.; Razali, M.; Otsuka, Y. Surface modifications and their effects on titanium dental implants. BioMed Res. Int. 2015, 2015, 791725. [CrossRef]

29. Lewallen, E.A.; Riester, S.M.; Bonin, C.A.; Kremers, H.M.; Dudakovic, A.; Kakar, S.; Cohen, R.C.; Westendorf, J.J.; Lewallen, D.G.; Van Wijnen, A.J. Biological strategies for improved osseointegration and osteoinduction of porous metal orthopedic implants. Tissue Eng. Part B Rev. 2015, 21, 218-230. [CrossRef] [PubMed]

30. Heng, B.C.; Bezerra, P.P.; Preiser, P.R.; Alex Law, S.; Xia, Y.; Boey, F.; Venkatraman, S.S. Effect of cell-seeding density on the proliferation and gene expression profile of human umbilical vein endothelial cells within ex vivo culture. Cytotherapy 2011, 13, 606-617. [CrossRef] [PubMed]

31. e Silva, C.W.M.; Alves, E.; Ramos, A.; Sandu, C.S.; Cavaleiro, A. Adhesion failures on hard coatings induced by interface anomalies. Vacuum 2009, 83, 1213-1217. [CrossRef]

32. Khlifi, K.; Ben Cheikh Larbi, A. Investigation of adhesion of PVD coatings using various approaches. Surf. Eng. 2013, 29, 555-560. [CrossRef]

33. Wieszczycka, K.; Staszak, K.; Woźniak-Budych, M.J.; Litowczenko, J.; Maciejewska, B.M.; Jurga, S. Surface functionalization-The way for advanced applications of smart materials. Coord. Chem. Rev. 2021, 436, 213846. [CrossRef]

34. Mahan, J.E. Physical Vapor Deposition of Thin Films; John Wiley \& Sons, Inc.: Hoboken, NJ, USA, 2000.

35. Arnold, C.B.; Serra, P.; Piqué, A. Laser direct-write techniques for printing of complex materials. Mrs Bull. 2007, 32, 23-31. [CrossRef] 
36. Liu, X.; Du, D.; Mourou, G. Laser ablation and micromachining with ultrashort laser pulses. IEEE J. Quantum Electron. 1997, 33, 1706-1716. [CrossRef]

37. Gsaxner, C.; Wallner, J.; Chen, X.; Zemann, W.; Egger, J. Facial model collection for medical augmented reality in oncologic cranio-maxillofacial surgery. Sci. Data 2019, 6, 310. [CrossRef] [PubMed]

38. Drakakis, T.S.; Papadakis, G.; Sambani, K.; Filippidis, G.; Georgiou, S.; Gizeli, E.; Fotakis, C.; Farsari, M. Construction of three-dimensional biomolecule structures employing femtosecond lasers. Appl. Phys. Lett. 2006, 89, 144108. [CrossRef]

39. Qadir, M.; Li, Y.; Wen, C. Ion-substituted calcium phosphate coatings by physical vapor deposition magnetron sputtering for biomedical applications: A review. Acta Biomater. 2019, 89, 14-32. [CrossRef] [PubMed]

40. Garcia-Sanz, F.; Mayor, M.; Arias, J.; Pou, J.; Leon, B.; Perez-Amor, M. Hydroxyapatite coatings: A comparative study between plasma-spray and pulsed laser deposition techniques. J. Mater. Sci. Mater. Med. 1997, 8, 861-865. [CrossRef] [PubMed]

41. Visan, A.; Cristescu, R.; Stefan, N.; Miroiu, M.; Nita, C.; Socol, M.; Florica, C.; Rasoga, O.; Zgura, I.; Sima, L. Antimicrobial polycaprolactone/polyethylene glycol embedded lysozyme coatings of $\mathrm{Ti}$ implants for osteoblast functional properties in tissue engineering. Appl. Surf. Sci. 2017, 417, 234-243. [CrossRef]

42. DeMuth, P.C.; Su, X.; Samuel, R.E.; Hammond, P.T.; Irvine, D.J. Nano-layered microneedles for transcutaneous delivery of polymer nanoparticles and plasmid DNA. Adv. Mater. 2010, 22, 4851-4856. [CrossRef] [PubMed]

43. Bohandy, J.; Kim, B.; Adrian, F. Metal deposition from a supported metal film using an excimer laser. J. Appl. Phys. 1986, 60, 1538-1539. [CrossRef]

44. Hwang, D.; Kim, J.-Y.; Kim, H.-s.; Lee, M.G. Novel stage with voice coil motor for laser beam direct writing. In Proceedings of the ASPE Spring Topical Meeting, Zürich, Switzerland; 2008; pp. 39-43.

45. Boutopoulos, C.; Tsouti, V.; Goustouridis, D.; Chatzandroulis, S.; Zergioti, I. Liquid phase direct laser printing of polymers for chemical sensing applications. Appl. Phys. Lett. 2008, 93, 191109. [CrossRef]

46. Banks, D.P.; Grivas, C.; Mills, J.D.; Eason, R.W.; Zergioti, I. Nanodroplets deposited in microarrays by femtosecond Ti: Sapphire laser-induced forward transfer. Appl. Phys. Lett. 2006, 89, 193107. [CrossRef]

47. Huang, Y.; Zheng, N.; Cheng, Z.; Chen, Y.; Lu, B.; Xie, T.; Feng, X. Direct laser writing-based programmable transfer printing via bioinspired shape memory reversible adhesive. ACS Appl. Mater. Interfaces 2016, 8, 35628-35633. [CrossRef]

48. Dutta Majumdar, J.; Manna, I. Laser material processing. Int. Mater. Rev. 2011, 56, 341-388. [CrossRef]

49. Jansen, E.D.; Frenz, M.; Kadipasaoglu, K.A.; Pfefer, T.J.; Altermatt, H.J.; Motamedi, M.; Welch, A.J. Laser-tissue interaction during transmyocardial laser revascularization. In Proceedings of the Lasers in Surgery: Advanced Characterization, Therapeutics, and Systems VI; SPIE Digital Library: Bellingham, WA, USA, 1996; pp. 49-57.

50. Malinauskas, M.; Gilbergs, H.; Žukauskas, A.; Purlys, V.; Paipulas, D.; Gadonas, R. A femtosecond laser-induced two-photon photopolymerization technique for structuring microlenses. J. Opt. 2010, 12, 035204. [CrossRef]

51. Kruth, J.P.; Mercelis, P.; Van Vaerenbergh, J.; Froyen, L.; Rombouts, M. Binding mechanisms in selective laser sintering and selective laser melting. Rapid Prototyp. J. 2005, 11, 1-16. [CrossRef]

52. Zhang, X.; Jiang, X.; Sun, C. Micro-stereolithography of polymeric and ceramic microstructures. Sens. Actuators A Phys. 1999, 77, 149-156. [CrossRef]

53. Gittard, S.D.; Narayan, R.J. Laser direct writing of micro-and nano-scale medical devices. Expert Rev. Med. Devices 2010, 7 , 343-356. [CrossRef]

54. Finazzi, V.; Demir, A.G.; Biffi, C.A.; Migliavacca, F.; Petrini, L.; Previtali, B. Design and functional testing of a novel balloonexpandable cardiovascular stent in CoCr alloy produced by selective laser melting. J. Manuf. Process. 2020, 55, 161-173. [CrossRef]

55. Laoui, T.; Santos, E.; Osakada, K.; Shiomi, M.; Morita, M.; Shaik, S.; Tolochko, N.; Abe, F.; Takahashi, M. Properties of titanium dental implant models made by laser processing. Proc. Inst. Mech. Eng. Part C J. Mech. Eng. Sci. 2006, 220, 857-863. [CrossRef]

56. Karami, K.; Blok, A.; Weber, L.; Ahmadi, S.; Petrov, R.; Nikolic, K.; Borisov, E.; Leeflang, S.; Ayas, C.; Zadpoor, A. Continuous and pulsed selective laser melting of Ti6Al4V lattice structures: Effect of post-processing on microstructural anisotropy and fatigue behaviour. Addit. Manuf. 2020, 36, 101433. [CrossRef]

57. Singh, S.; Sharma, S. Micromachining of polyurethane (PU) polymer using a KrF excimer laser (248 nm). Appl. Surf. Sci. 2014, 321, 289-301. [CrossRef]

58. Bradford, S.; Mikula, E.; Xie, Y.; Juhasz, T.; Brown, D.J.; Jester, J.V. Enhanced transepithelial riboflavin delivery using femtosecond laser-machined epithelial microchannels. Transl. Vis. Sci. Technol. 2020, 9, 1. [CrossRef]

59. Al-Kattan, A.; Grojo, D.; Drouet, C.; Mouskeftaras, A.; Delaporte, P.; Casanova, A.; Robin, J.D.; Magdinier, F.; Alloncle, P.; Constantinescu, C. Short-Pulse Lasers: A Versatile Tool in Creating Novel Nano-/Micro-Structures and Compositional Analysis for Healthcare and Wellbeing Challenges. Nanomaterials 2021, 11, 712. [CrossRef] [PubMed]

60. Ackerl, N.; Warhanek, M.; Gysel, J.; Wegener, K. Ultrashort-pulsed laser machining of dental ceramic implants. J. Eur. Ceram. Soc. 2019, 39, 1635-1641. [CrossRef]

61. Negut, I.; Visan, A.I.; Popescu, C.; Cristescu, R.; Ficai, A.; Grumezescu, A.M.; Chifiriuc, M.C.; Boehm, R.D.; Yamaleyeva, D.; Taylor, M. Successful release of voriconazole and flavonoids from MAPLE deposited bioactive surfaces. Appl. Sci. 2019,9 , 786. [CrossRef]

62. Duta, L.; Ristoscu, C.; Stan, G.; Husanu, M.; Besleaga, C.; Chifiriuc, M.; Lazar, V.; Bleotu, C.; Miculescu, F.; Mihailescu, N New bio-active, antimicrobial and adherent coatings of nanostructured carbon double-reinforced with silver and silicon by Matrix-Assisted Pulsed Laser Evaporation for medical applications. Appl. Surf. Sci. 2018, 441, 871-883. [CrossRef] 
63. Koch, L.; Deiwick, A.; Chichkov, B. Laser-Based Cell Printing. 3D Print. Biofabr. 2018, 1, 303-329.

64. Gómez, S.; Vlad, M.; López, J.; Fernández, E. Design and properties of 3D scaffolds for bone tissue engineering. Acta Biomater. 2016, 42, 341-350. [CrossRef]

65. Bernasconi, R.; Cuneo, F.; Carrara, E.; Chatzipirpiridis, G.; Hoop, M.; Chen, X.; Nelson, B.J.; Pané, S.; Credi, C.; Levi, M. Hard-magnetic cell microscaffolds from electroless coated 3D printed architectures. Mater. Horiz. 2018, 5, 699-707. [CrossRef]

66. Zhang, L.G.; Fisher, J.P.; Leong, K. 3D Bioprinting and Nanotechnology in Tissue Engineering and Regenerative Medicine; Academic Press: Cambridge, MA, USA, 2015.

67. Ravi-Kumar, S.; Lies, B.; Zhang, X.; Lyu, H.; Qin, H. Laser ablation of polymers: A review. Polym. Int. 2019, 68, 1391-1401. [CrossRef]

68. Beck, R.; Bitharas, I.; Hand, D.; Maisey, T.; Moore, A.; Shires, M.; Thomson, R.; West, N.; Jayne, D.; Shephard, J. Dynamics of picosecond laser ablation for surgical treatment of colorectal cancer. Sci. Rep. 2020, 10, 20261. [CrossRef]

69. Hirohara, M.; Maekawa, T.; Mondarte, E.A.Q.; Nyu, T.; Mizushita, Y.; Hayashi, T. Proteomic analysis of biomaterial surfaces after contacting with body fluids by MALDI-ToF mass spectroscopy. Coatings 2020, 10, 12. [CrossRef]

70. Strnad, Š.; Vrkoslav, V.; Klimšová, Z.; Zemenová, J.; Cvačka, J.; Maletínská, L.; Sýkora, D. Application of matrix-assisted laser desorption/ionization mass spectrometry imaging in combination with LC-MS in pharmacokinetic study of metformin Bioanalysis 2018, 10, 71-81. [CrossRef] [PubMed]

71. Granzotto, C.; Sutherland, K. Matrix assisted laser desorption ionization mass fingerprinting for identification of Acacia gum in microsamples from works of art. Anal. Chem. 2017, 89, 3059-3068. [CrossRef] [PubMed]

72. Popescu-Pelin, G.-F.; Ristoscu, C.; Badiceanu, M.; Mihailescu, I.N. Protected Laser Evaporation/Ablation and Deposition of Organic/Biological Materials: Thin Films Deposition for Nanobiomedical Applications. In Laser Ablation-From Fundamentals to Applications; Idina, T., Ed.; IntechOpen: London, UK, 2017; pp. 57-79.

73. Nikolov, A.; Stankova, N.; Karashanova, D.; Nedyalkov, N.; Pavlov, E.; Koev, K.T.; Najdenski, H.; Kussovski, V.; Avramov, L.; Ristoscu, C. Synergistic effect in a two-phase laser procedure for production of silver nanoparticles colloids applicable in ophthalmology. Opt. Laser Technol. 2021, 138, 106850. [CrossRef]

74. D'alessio, L.; Ferro, D.; Marotta, V.; Santagata, A.; Teghil, R.; Zaccagnino, M. Laser ablation and deposition of Bioglass ${ }^{\circledR} 45 S 5$ thin films. Appl. Surf. Sci. 2001, 183, 10-17. [CrossRef]

75. Teghil, R.; Curcio, M.; De Bonis, A. Substituted hydroxyapatite, glass, and glass-ceramic thin films deposited by nanosecond pulsed laser deposition (PLD) for biomedical applications: A systematic review. Coatings 2021, 11, 811. [CrossRef]

76. Moreno-Vilet, L.; Bostyn, S.; Flores-Montaño, J.-L.; Camacho-Ruiz, R.-M. Comparative data of molecular weight distribution of agave fructans fractions using MALDI-ToF and HPLC-SEC. Data Brief 2019, 24, 103984. [CrossRef]

77. Lai, Y.-H.; Wang, Y.-S. Matrix-assisted laser desorption/ionization mass spectrometry: Mechanistic studies and methods for improving the structural identification of carbohydrates. Mass Spectrom. 2017, 6, S0072. [CrossRef]

78. Sima, F.; Mihailescu, I.N. Biomimetic assemblies by matrix-assisted pulsed laser evaporation. In Laser Technology in Biomimetics; Springer: Berlin/Heidelberg, Germany, 2013; pp. 111-141.

79. Yang, S.; Zhang, J. Matrix-Assisted Pulsed Laser Evaporation (MAPLE) technique for deposition of hybrid nanostructures. Front. Nanosci. Nanotechnol. 2017, 3, 1. [CrossRef]

80. Bloisi, F.; Barra, M.; Cassinese, A.; Vicari, L.R.M. Matrix-assisted pulsed laser thin film deposition by using Nd: YAG laser. J. Nanomater. 2012, 2012, 395436. [CrossRef]

81. Papavlu, A.P.; Dinca, V.; Filipescu, M.; Dinescu, M. Matrix-assisted pulsed laser evaporation of organic thin gilms: Applications in biology and chemical sensors. In Laser Ablation_From Fundamentals to Applications; Itina, T.E., Ed.; InTech: Rijeka, Croatia, 2017; pp. 171-189.

82. Mahamood, R.M.; Akinlabi, E.T.; Shukla, M.; Pityana, S. Revolutionary Additive Manufacturing: An Overview. Lasers Eng. 2014, 27, 161-178.

83. Kokkinaki, O.; Georgiou, S. Laser ablation of cryogenic films: Implications to matrix-assisted pulsed laser deposition of biopolymers and dedicated applications in nanotechnology. Dig. J. Nanomater. Biostruct. 2007, 2, 221-241.

84. Stiff-Roberts, A.D.; Ge, W. Organic/hybrid thin films deposited by matrix-assisted pulsed laser evaporation (MAPLE). Appl. Phys. Rev. 2017, 4, 041303. [CrossRef]

85. Tabetah, M.; Matei, A.; Constantinescu, C.; Mortensen, N.P.; Dinescu, M.; Schou, J.; Zhigilei, L.V. The minimum amount of "matrix" needed for matrix-assisted pulsed laser deposition of biomolecules. J. Phys. Chem. B 2014, 118, 13290-13299. [CrossRef]

86. Adcock, S.A.; McCammon, J.A. Molecular dynamics: Survey of methods for simulating the activity of proteins. Chem. Rev. 2006, 106, 1589-1615. [CrossRef]

87. Hollingsworth, S.A.; Dror, R.O. Molecular dynamics simulation for all. Neuron 2018, 99, 1129-1143. [CrossRef]

88. Sopronyi, M.; Nita, C.; Le Meins, J.-M.; Vidal, L.; Jipa, F.; Axente, E.; Ghimbeu, C.M.; Sima, F. Laser-assisted synthesis of carbon coatings with cobalt oxide nanoparticles embedded in gradient of composition and sizes. Surf. Coat. Technol. 2021, $419,127301$. [CrossRef]

89. Chen, J.; An, Q.; Ming, W.; Chen, M. Investigations on continuous-wave laser and pulsed laser induced controllable ablation of SiCf/SiC composites. J. Eur. Ceram. Soc. 2021, 41, 5835-5849. [CrossRef] 
90. Cristescu, R.; Popescu, C.; Dorcioman, G.; Miroiu, F.; Socol, G.; Mihailescu, I.; Gittard, S.; Miller, P.; Narayan, R.; Enculescu, M. Antimicrobial activity of biopolymer-antibiotic thin films fabricated by advanced pulsed laser methods. Appl. Surf. Sci. 2013, 278, 211-213. [CrossRef]

91. Grumezescu, V.; Socol, G.; Grumezescu, A.M.; Holban, A.M.; Ficai, A.; Truşcă, R.; Bleotu, C.; Balaure, P.C.; Cristescu, R.; Chifiriuc, M.C. Functionalized antibiofilm thin coatings based on PLA-PVA microspheres loaded with usnic acid natural compounds fabricated by MAPLE. Appl. Surf. Sci. 2014, 302, 262-267. [CrossRef]

92. Gaabour, L.; Hamam, K. The modification and development of the spectroscopic properties of Cs/PVA blend incorporated gold nanoparticles (AuNPs) prepared by pulsed laser ablation in liquids (PLAL). Dig. J. Nanomater. Biostruct. 2020, 15, 973-983.

93. Cristescu, R.; Dorcioman, G.; Ristoscu, C.; Axente, E.; Grigorescu, S.; Moldovan, A.; Mihailescu, I.; Kocourek, T.; Jelinek, M.; Albulescu, M. Matrix assisted pulsed laser evaporation processing of triacetate-pullulan polysaccharide thin films for drug delivery systems. Appl. Surf. Sci. 2006, 252, 4647-4651. [CrossRef]

94. Sima, F.; Axente, E.; Sima, L.; Tuyel, U.; Eroglu, M.; Serban, N.; Ristoscu, C.; Petrescu, S.; Toksoy Oner, E.; Mihailescu, I. Combinatorial matrix-assisted pulsed laser evaporation: Single-step synthesis of biopolymer compositional gradient thin film assemblies. Appl. Phys. Lett. 2012, 101, 233705. [CrossRef]

95. Takeuchi, I. Combinatorial pulsed laser deposition. In Pulsed Laser Depos. Pulsed Laser Deposition of Thin Films: Applications-Led Growth of Functional Materials; John Wiley \& Sons, Inc.: Hoboken, NJ, USA, 2007; pp. 161-175.

96. Socol, G.; Socol, M.; Sima, L.; Petrescu, S.; Enculescu, M.; Sima, F.; Miroiu, M.; Popescu-Pelin, G.; Stefan, N.; Cristescu, R. Combinatorial pulsed laser deposition of Ag-containing calcium phosphate coatings. Dig. J. Nanomater. Biostruct. 2012, 7, 563-576.

97. Mihailescu, I.N.; Bociaga, D.; Socol, G.; Stan, G.E.; Chifiriuc, M.-C.; Bleotu, C.; Husanu, M.A.; Popescu-Pelin, G.; Duta, L.; Luculescu, C.R. Fabrication of antimicrobial silver-doped carbon structures by combinatorial pulsed laser deposition. Int. J. Pharm. 2016, 515, 592-606. [CrossRef]

98. Axente, E.; Sima, F. Biomimetic nanostructures with compositional gradient grown by combinatorial matrix-assisted pulsed laser evaporation for tissue engineering. Curr. Med. Chem. 2020, 27, 903-918. [CrossRef]

99. Smausz, T.; Megyeri, G.; Kékesi, R.; Vass, C.; György, E.; Sima, F.; Mihailescu, I.N.; Hopp, B. Comparative study on pulsed laser deposition and matrix assisted pulsed laser evaporation of urease thin films. Thin Solid Films 2009, 517, 4299-4302. [CrossRef]

100. Axente, E.; Ristoscu, C.; Bigi, A.; Sima, F.; Mihailescu, I.N. Combinatorial laser synthesis of biomaterial thin films: Selection and processing for medical applications. In Advances in the Application of Lasers in Materials Science; Springer: Berlin/Heidelberg, Germany, 2018; pp. 309-338.

101. Sima, F.; Axente, E.; Iordache, I.; Luculescu, C.; Gallet, O.; Anselme, K.; Mihailescu, I. Combinatorial matrix assisted pulsed laser evaporation of a biodegradable polymer and fibronectin for protein immobilization and controlled release. Appl. Surf. Sci. 2014 306, 75-79. [CrossRef]

102. Sima, L.E.; Chiritoiu, G.; Negut, I.; Grumezescu, V.; Orobeti, S.; Munteanu, C.V.; Sima, F.; Axente, E. Functionalized graphene oxide thin films for anti-tumor drug delivery to melanoma cells. Front. Chem. 2020, 8, 184. [CrossRef]

103. Negut, I.; Floroian, L.; Ristoscu, C.; Mihailescu, C.N.; Mirza Rosca, J.C.; Tozar, T.; Badea, M.; Grumezescu, V.; Hapenciuc, C.; Mihailescu, I.N. Functional bioglass-Biopolymer double nanostructure for natural antimicrobial drug extracts delivery. Nanomaterials 2020, 10, 385. [CrossRef]

104. Socol, M.; Preda, N.; Breazu, C.; Costas, A.; Petre, G.; Stanculescu, A.; Popescu-Pelin, G.; Mihailescu, A.; Socol, G. Organic Thin Films Based on DPP-DTT: C60 Blends Deposited by MAPLE. Nanomaterials 2020, 10, 2366. [CrossRef]

105. Piqué, A. Deposition of Polymers and Biomaterials Using the Matrix-Assisted Pulsed Laser Evaporation (MAPLE) Process; John Wiley \& Sons: Hoboken, NJ, USA, 2007; Volume 3.

106. Mihailescu, N.; Haskoylu, M.E.; Ristoscu, C.; Bostan, M.S.; Sopronyi, M.; Eroğlu, M.S.; Chifiriuc, M.C.; Mustaciosu, C.C.; Axente, E.; Oner, E.T. Gradient multifunctional biopolymer thin film assemblies synthesized by combinatorial MAPLE. Appl. Surf. Sci. 2019, 466, 628-636. [CrossRef]

107. Boanini, E.; Torricelli, P.; Sima, F.; Axente, E.; Fini, M.; Mihailescu, I.N.; Bigi, A. Gradient coatings of strontium hydroxyapatite/zinc $\beta$-tricalcium phosphate as a tool to modulate osteoblast/osteoclast response. J. Inorg. Biochem. 2018, 183, 1-8. [CrossRef]

108. Braun, M. Magnetron sputtering technique. In Handbook of Manufacturing Engineering Technology; Springer: Berlin, Germany, 2015; pp. 2929-2957.

109. Safavi, M.S.; Surmeneva, M.A.; Surmenev, R.A.; Khalil-Allafi, J. RF-magnetron sputter deposited hydroxyapatite-based composite \& multilayer coatings: A systematic review from mechanical, corrosion, and biological points of view. Ceram. Int. 2021, 47, 3031-3053.

110. Han, J.G. Recent progress in thin film processing by magnetron sputtering with plasma diagnostics. J. Phys. D Appl. Phys. 2009, 42, 043001. [CrossRef]

111. Khan, S.; Shahid, M.; Mahmood, A.; Shah, A.; Ahmed, I.; Mehmood, M.; Aziz, U.; Raza, Q.; Alam, M. Texture of the nanocrystalline AlN thin films and the growth conditions in DC magnetron sputtering. Prog. Nat. Sci. Mater. Int. 2015, 25, 282-290. [CrossRef]

112. Mazhir, S.N.; Khalaf, M.K.; Taha, S.K.; Mohsin, H.K. Measurement of plasma electron temperature and density by using different applied voltages and working pressures in a magnetron sputtering system. Int. J. Eng. Technol 2018, 7, 1177-1180. [CrossRef] 
113. How, S.R.; Nayan, N.; Lias, J.; Ahmad, M.K.; Sahdan, M.Z.; Mamat, M.H.; Mahmood, M.R.; Aldalbahi, A. Plasma diagnostic by optical emission spectroscopy on reactive magnetron sputtering plasma-A Brief Introduction. In Journal of Physics: Conference Series; IOP Publishing: Tokyo, Japan, 2018; Volume 1027, p. 012005.

114. Hartmann, H.; Popok, V.; Barke, I.; von Oeynhausen, V.; Meiwes-Broer, K.-H. Design and capabilities of an experimental setup based on magnetron sputtering for formation and deposition of size-selected metal clusters on ultra-clean surfaces. Rev. Sci. Instrum. 2012, 83, 073304. [CrossRef]

115. Shi, J.; Chen, C.; Yu, H.; Zhang, S. Application of magnetron sputtering for producing bioactive ceramic coatings on implant materials. Bull. Mater. Sci. 2008, 31, 877. [CrossRef]

116. Coe, S.C.; Wadge, M.D.; Felfel, R.M.; Ahmed, I.; Walker, G.S.; Scotchford, C.A.; Grant, D.M. Production of high silicon-doped hydroxyapatite thin film coatings via magnetron sputtering: Deposition, characterisation, and in vitro biocompatibility. Coatings 2020, 10, 190. [CrossRef]

117. Kang, K.-N.; Lee, J.; Lee, K.Y.; Park, Y.S. Tribological and electrical properties of chromium-doped carbon films fabricated by unbalanced magnetron sputtering for medical stents. J. Nanosci. Nanotechnol. 2019, 19, 1415-1419. [CrossRef]

118. Yang, Y.-J.; Tsou, H.-K.; Chen, Y.-H.; Chung, C.-J.; He, J.-L. Enhancement of bioactivity on medical polymer surface using high power impulse magnetron sputtered titanium dioxide film. Mater. Sci. Eng. C 2015, 57, 58-66. [CrossRef] [PubMed]

119. Sugumaran, A.A.; Shukla, K.; Khan, I.; Ehiasarian, A.P.; Hovsepian, P.E. Dry sliding wear mechanisms of HIPIMS plasma nitrided CoCrMo alloy for medical implant applications. Vacuum 2021, 185, 109994. [CrossRef]

120. Gomes, O.P.; Neto, N.F.A.; Bronze-Uhle, E.S.; Trino, L.D.; dos Santos, C.M.; da Silva, J.H.; Lisboa-Filho, P.N. 3-Mercaptopropionic acid functionalization of titanium dioxide thin films. Mater. Chem. Phys. 2019, 223, 32-38. [CrossRef]

121. Kumarasubramanian, R.; Kumar, D.D.; Preetham, R.M.S.; Reddy, P.B.K. Deposition and characterization Zr-Al-N coatings prepared by magnetron sputtering for tribological applications. Mater. Today Proc. 2021, 44, 3701-3706. [CrossRef]

122. Bociaga, D.; Sobczyk-Guzenda, A.; Szymanski, W.; Jedrzejczak, A.; Jastrzebska, A.; Olejnik, A.; Swiatek, L.; Jastrzebski, K. Diamond like carbon coatings doped by Si fabricated by a multi-target DC-RF magnetron sputtering method-Mechanical properties, chemical analysis and biological evaluation. Vacuum 2017, 143, 395-406. [CrossRef]

123. Naga, V.; Nehate, S.D.; Saikumar, A.K.; Sundaram, K.B. Boron carbon nitride (BCN) nano-coatings of central venous catheters inhibits bacterial colonization. ECS J. Solid State Sci. Technol. 2020, 9, 115018. [CrossRef]

124. Stan, G.; Popa, A.; Galca, A.; Aldica, G.; Ferreira, J. Strong bonding between sputtered bioglass-ceramic films and Ti-substrate implants induced by atomic inter-diffusion post-deposition heat-treatments. Appl. Surf. Sci. 2013, 280, 530-538. [CrossRef]

125. Tite, T.; Popa, A.; Chirica, I.; Stuart, B.; Galca, A.; Balescu, L.; Popescu-Pelin, G.; Grant, D.; Ferreira, J.; Stan, G. Phosphate bioglass thin-films: Cross-area uniformity, structure and biological performance tailored by the simple modification of magnetron sputtering gas pressure. Appl. Surf. Sci. 2021, 541, 148640. [CrossRef]

126. Popa, A.; Marques, V.; Stan, G.; Husanu, M.; Galca, A.; Ghica, C.; Tulyaganov, D.; Lemos, A.; Ferreira, J. Nanomechanical characterization of bioglass films synthesized by magnetron sputtering. Thin Solid Films 2014, 553, 166-172. [CrossRef]

127. Stuart, B.; Stan, G.; Popa, A.; Carrington, M.; Zgura, I.; Necsulescu, M.; Grant, D. New solutions for combatting implant bacterial infection based on silver nano-dispersed and gallium incorporated phosphate bioactive glass sputtered films: A preliminary study. Bioact. Mater. 2022, 8, 325-340. [CrossRef]

128. Popa, A.; Fernandes, H.; Necsulescu, M.; Luculescu, C.; Cioangher, M.; Dumitru, V.; Stuart, B.; Grant, D.; Ferreira, J.; Stan, G. Antibacterial efficiency of alkali-free bio-glasses incorporating $\mathrm{ZnO}$ and/or $\mathrm{SrO}$ as therapeutic agents. Ceram. Int. 2019, 45, 4368-4380. [CrossRef]

129. ASTM F2792-10e1; Standard Additive Manufacturing-General Principles-Terminology. ASTM: West Conshohocken, PA, USA, 2015.

130. Tiwari, D.; Vobilisetty, R.K.; Heer, B. Current Application and Future Prospects of 3D Printing in Otorhinolaryngology-A Narrative Review. Indian J. Otolaryngol. Head Neck Surg. 2021, 1, 1-4. [CrossRef]

131. Hull, R.; Sadler, J.; Longstaff, M. The sequence of carnation etched ring virus DNA: Comparison with cauliflower mosaic virus and retroviruses. EMBO J. 1986, 5, 3083-3090. [CrossRef] [PubMed]

132. Wu, J.-J.; Huang, L.-M.; Zhao, Q.; Xie, T. 4D printing: History and recent progress. Chin. J. Polym. Sci. 2018, 36, 563-575. [CrossRef]

133. Tofail, S.A.; Koumoulos, E.P.; Bandyopadhyay, A.; Bose, S.; O’Donoghue, L.; Charitidis, C. Additive manufacturing: Scientific and technological challenges, market uptake and opportunities. Mater. Today 2018, 21, 22-37. [CrossRef]

134. Shirazi, S.F.S.; Gharehkhani, S.; Mehrali, M.; Yarmand, H.; Metselaar, H.S.C.; Kadri, N.A.; Osman, N.A.A. A review on powderbased additive manufacturing for tissue engineering: Selective laser sintering and inkjet 3D printing. Sci. Technol. Adv. Mater. 2015, 16, 033502. [CrossRef]

135. Yan, Q.; Dong, H.; Su, J.; Han, J.; Song, B.; Wei, Q.; Shi, Y. A review of 3D printing technology for medical applications. Engineering 2018, 4, 729-742. [CrossRef]

136. Masood, S.H. Advances in Fused Deposition Modeling. In Comprehensive Materials Processing; Saleem Hashmi, G.F.B., Chester, J., Van Tyne, B.Y., Eds.; Elsevier: Amsterdam, The Netherlands, 2014; Volume 10, pp. 69-91.

137. Saturno, M.; Pertel, V.M.; Deschamps, F.; Loures, E. Proposal for new automation architecture solutions for industry 4.0. LogForum 2018, 14, 185-195. [CrossRef]

138. Kumar, P.; Rajak, D.K.; Abubakar, M.; Ali, S.G.M.; Hussain, M. 3D Printing Technology for Biomedical Practice: A Review. J. Mater. Eng. Perform. 2021, 30, 5342-5355. [CrossRef] 
139. Loai, S.; Kingston, B.R.; Wang, Z.; Philpott, D.N.; Tao, M.; Cheng, H.-L.M. Clinical perspectives on 3D bioprinting paradigms for regenerative medicine. Regen. Med. Front. 2019, 1, e190004.

140. Leberfinger, A.N.; Ravnic, D.J.; Dhawan, A.; Ozbolat, I.T. Concise review: Bioprinting of stem cells for transplantable tissue fabrication. Stem Cells Transl. Med. 2017, 6, 1940-1948. [CrossRef]

141. Matai, I.; Kaur, G.; Seyedsalehi, A.; McClinton, A.; Laurencin, C.T. Progress in 3D bioprinting technology for tissue/organ regenerative engineering. Biomaterials 2020, 226, 119536. [CrossRef]

142. Gokuldoss, P.K.; Kolla, S.; Eckert, J. Additive manufacturing processes: Selective laser melting, electron beam melting and binder jetting-Selection guidelines. Materials 2017, 10, 672. [CrossRef] [PubMed]

143. Sercombe, T.; Zhang, L.-C.; Li, S.; Hao, Y. Additive manufacturing of cp-Ti, Ti-6Al-4V and Ti2448. In Titanium in Medical and Dental Applications; Elsevier: Amsterdam, The Netherlands, 2018; pp. 303-324.

144. Singh, N.; Hameed, P.; Ummethala, R.; Manivasagam, G.; Prashanth, K.; Eckert, J. Selective laser manufacturing of Ti-based alloys and composites: Impact of process parameters, application trends, and future prospects. Mater. Today Adv. 2020, 8, 100097. [CrossRef]

145. Li, J.; Chen, M.; Fan, X.; Zhou, H. Recent advances in bioprinting techniques: Approaches, applications and future prospects. J. Transl. Med. 2016, 14, 271. [CrossRef]

146. Ma, M.; Song, K.; Ji, Y.; Hussain, F.; Khesro, A.; Mao, M.; Xue, L.; Xu, P.; Liu, B.; Lu, Z. 5 G microstrip patch antenna and microwave dielectric properties of cold sintered LiWVO6-K2MoO4 composite ceramics. Ceram. Int. 2021, 47, 19241-19246. [CrossRef]

147. Lathers, S.; La Belle, J. Advanced manufactured fused filament fabrication 3D printed osseointegrated prosthesis for a transhumeral amputation using Taulman 680 FDA. 3D Print. Addit. Manuf. 2016, 3, 166-174. [CrossRef]

148. Bose, S.; Bhattacharjee, A.; Banerjee, D.; Boccaccini, A.R.; Bandyopadhyay, A. Influence of random and designed porosities on 3D printed tricalcium phosphate-bioactive glass scaffolds. Addit. Manuf. 2021, 40, 101895. [CrossRef]

149. Bishop, E.S.; Mostafa, S.; Pakvasa, M.; Luu, H.H.; Lee, M.J.; Wolf, J.M.; Ameer, G.A.; He, T.-C.; Reid, R.R. 3-D bioprinting technologies in tissue engineering and regenerative medicine: Current and future trends. Genes Dis. 2017, 4, 185-195. [CrossRef] [PubMed]

150. Cho, Y.S.; Choi, S.; Lee, S.-H.; Kim, K.K.; Cho, Y.-S. Assessments of polycaprolactone/hydroxyapatite composite scaffold with enhanced biomimetic mineralization by exposure to hydroxyapatite via a 3D-printing system and alkaline erosion. Eur. Polym. J. 2019, 113, 340-348. [CrossRef]

151. Fu, Z.; Naghieh, S.; Xu, C.; Wang, C.; Sun, W.; Chen, X. Printability in extrusion bioprinting. Biofabrication 2021, 13, 033001 [CrossRef]

152. Rajzer, I.; Stręk, P.; Wiatr, M.; Skladzien, J.; Kurowska, A.; Kopeć, J.; Swiezy, K.; Wiatr, A. Biomaterials in the reconstruction of nasal septum perforation. Ann. Otol. Rhinol. Laryngol. 2021, 130, 731-737. [CrossRef] [PubMed]

153. Salentijn, G.I.; Oomen, P.E.; Grajewski, M.; Verpoorte, E. Fused deposition modeling 3D printing for (bio) analytical device fabrication: Procedures, materials, and applications. Anal. Chem. 2017, 89, 7053-7061. [CrossRef]

154. Diez-Escudero, A.; Andersson, B.; Persson, C.; Hailer, N.P. Hexagonal pore geometry and the presence of hydroxyapatite enhance deposition of mineralized bone matrix on additively manufactured polylactic acid scaffolds. Mater. Sci. Eng. C 2021, $125,112091$. [CrossRef]

155. Irvine, S.A.; Venkatraman, S.S. Bioprinting and differentiation of stem cells. Molecules 2016, 21, 1188. [CrossRef] [PubMed]

156. McCracken, J.M.; Rauzan, B.M.; Kjellman, J.C.; Kandel, M.E.; Liu, Y.H.; Badea, A.; Miller, L.A.; Rogers, S.A.; Popescu, G.; Nuzzo, R.G. 3D-Printed Hydrogel Composites for Predictive Temporal (4D) Cellular Organizations and Patterned Biogenic Mineralization. Adv. Healthc. Mater. 2019, 8, 1800788. [CrossRef]

157. Christensen, K.; Compaan, A.; Chai, W.; Xia, G.; Huang, Y. In situ printing-then-mixing for biological structure fabrication using intersecting jets. ACS Biomater. Sci. Eng. 2017, 3, 3687-3694. [CrossRef] [PubMed]

158. Sakurada, S.; Sole-Gras, M.; Christensen, K.; Wallace, D.B.; Huang, Y. Liquid-absorbing system-assisted intersecting jets printing of soft structures from reactive biomaterials. Addit. Manuf. 2020, 31, 100934. [CrossRef]

159. Müller, M.; Becher, J.; Schnabelrauch, M.; Zenobi-Wong, M. Printing thermoresponsive reverse molds for the creation of patterned two-component hydrogels for 3D cell culture. J. Vis. Exp. JoVE 2013. [CrossRef]

160. Yoon, S.; Park, J.A.; Lee, H.R.; Yoon, W.H.; Hwang, D.S.; Jung, S. Inkjet-spray hybrid printing for 3D freeform fabrication of multilayered hydrogel structures. Adv. Healthc. Mater. 2018, 7, 1800050. [CrossRef]

161. Zhang, Y.; Yu, Y.; Chen, H.; Ozbolat, I.T. Characterization of printable cellular micro-fluidic channels for tissue engineering. Biofabrication 2013, 5, 025004. [CrossRef] [PubMed]

162. Gong, Y.; Wang, F.; Al-Furjan, M.; Shan, L.; He, J.; Bian, X.; Bi, Z.; Liu, H.; Li, W.; Shao, H. Experimental investigation and optimal 3D bioprinting parameters of SA-Gel porous cartilage scaffold. Appl. Sci. 2020, 10, 768. [CrossRef]

163. Lim, W.; Shin, S.Y.; Cha, J.M.; Bae, H. Optimization of Polysaccharide Hydrocolloid for the Development of Bioink with High Printability/Biocompatibility for Coextrusion 3D Bioprinting. Polymers 2021, 13, 1773. [CrossRef]

164. Freeman, S.; Ramos, R.; Chando, P.A.; Zhou, L.; Reeser, K.; Jin, S.; Soman, P.; Ye, K. A bioink blend for rotary 3D bioprinting tissue engineered small-diameter vascular constructs. Acta Biomater. 2019, 95, 152-164. [CrossRef] [PubMed]

165. Kobayashi, M.; Kadota, J.; Hashimoto, Y.; Fujisato, T.; Nakamura, N.; Kimura, T.; Kishida, A. Elastic modulus of ECM hydrogels derived from decellularized tissue affects capillary network formation in endothelial cells. Int. J. Mol. Sci. 2020, $21,6304$. [CrossRef] 
166. Ning, L.; Zhu, N.; Mohabatpour, F.; Sarker, M.; Schreyer, D.J.; Chen, X. Bioprinting Schwann cell-laden scaffolds from low-viscosity hydrogel compositions. J. Mater. Chem. B 2019, 7, 4538-4551. [CrossRef]

167. Kérourédan, O.; Bourget, J.-M.; Rémy, M.; Crauste-Manciet, S.; Kalisky, J.; Catros, S.; Thébaud, N.B.; Devillard, R. Micropatterning of endothelial cells to create a capillary-like network with defined architecture by laser-assisted bioprinting. J. Mater. Sci. Mater. Med. 2019, 30, 28. [CrossRef]

168. Hakobyan, D.; Médina, C.; Dusserre, N.; Stachowicz, M.-L.; Handschin, C.; Fricain, J.-C.; Guillermet-Guibert, J.; Oliveira, H. Laser-assisted 3D bioprinting of exocrine pancreas spheroid models for cancer initiation study. Biofabrication 2020, $12,035001$. [CrossRef]

169. Lee, Y.-B.; Polio, S.; Lee, W.; Dai, G.; Menon, L.; Carroll, R.S.; Yoo, S.-S. Bio-printing of collagen and VEGF-releasing fibrin gel scaffolds for neural stem cell culture. Exp. Neurol. 2010, 223, 645-652. [CrossRef]

170. Lee, V.; Singh, G.; Trasatti, J.P.; Bjornsson, C.; Xu, X.; Tran, T.N.; Yoo, S.-S.; Dai, G.; Karande, P. Design and fabrication of human skin by three-dimensional bioprinting. Tissue Eng. Part C Methods 2014, 20, 473-484. [CrossRef]

171. Tetik, H.; Wang, Y.; Sun, X.; Cao, D.; Shah, N.; Zhu, H.; Qian, F.; Lin, D. Additive Manufacturing of 3D Aerogels and Porous Scaffolds: A Review. Adv. Funct. Mater. 2021, 31, 2103410. [CrossRef]

172. Yap, Y.L.; Sing, S.L.; Yeong, W.Y. A review of 3D printing processes and materials for soft robotics. Rapid Prototyp. J. 2020, 26, 1345-1361. [CrossRef] 